\title{
Enantioselective approaches to Potential MetAP-2 reversible inhibitors
}

Vincent Rodeschini, Pierre Van de Weghe, Céline Tarnus, Emmanuel Salomon and Jacques

Eustache*

Supporting information 1

Table of contents:

S2 Preparation of 6

S3 Preparation of 7 and 8

S4 Preparation of $\mathbf{9}$ and $\mathbf{1 0}$

S5 Preparation of $\mathbf{1 1}$

S6 Preparation of $\mathbf{1 2}$ and $\mathbf{1 3}$

S7 Preparation of $\mathbf{1 4}$

S8 Preparation of 16 and 17

S10 Preparation of $\mathbf{1 8}$

S11 Preparation of 19, 20 and 22

S12 Preparation of $\mathbf{2 3}$

S13 Preparation of $\mathbf{2 5}$

S14 Preparation of $\mathbf{2 6}$ and $\mathbf{2 7}$

S15 Preparation of $\mathbf{2 8}$

S16 Preparation of $\mathbf{2 9}$ and $\mathbf{3 1}$

S17 Preparation of $\mathbf{3 2}$

S18 Preparation of $\mathbf{3 4}$ 
(6)

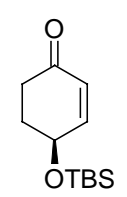

BuLi (1.6 M in hexane, $3.0 \mathrm{~mL}, 4.8 \mathrm{mmol}, 2.2$ equiv.) was added to a suspension of (+)-bis ( $\alpha$ methylbenzylamine) hydrochloride (630 mg, $2.4 \mathrm{mmol}, 1.1$ equiv.) in THF $(10 \mathrm{~mL})$ at $-78{ }^{\circ} \mathrm{C}$. The mixture was stirred at this temperature for $10 \mathrm{~min}$, and then at $0{ }^{\circ} \mathrm{C}$ for $5 \mathrm{~min}$. The yellow solution thus obtained was cooled to $-100{ }^{\circ} \mathrm{C}$ and $\mathrm{Me}_{3} \mathrm{SiCl}(1.3 \mathrm{~mL}, 11 \mathrm{mmol}, 5$ equiv.) was added, followed by a solution of $4(500 \mathrm{mg}, 2.2 \mathrm{mmol})$ in THF $(2.5 \mathrm{~mL})$. The mixture was stirred at this temperature for $3 \mathrm{~h}$, at which time $\mathrm{Et}_{3} \mathrm{~N}(6 \mathrm{~mL})$ was added. The solution was transferred via cannula to cool $\left(0^{\circ} \mathrm{C}\right)$ water. The organic layer was separated, and the aqueous phase was extracted twice with AcOEt. The combined organic phases were dried over $\mathrm{MgSO}_{4}$, filtered and evaporated in vacuo. The residue thus obtained was filtered over a short pad of silica gel (cyclohexane / AcOEt / $\mathrm{Et}_{3} \mathrm{~N}$ 95/5/0.5) to give the silyl enolether 5 (540 $\mathrm{mg}$, colorless oil). This was dissolved in DMSO $(20 \mathrm{~mL})$ and treated with $\mathrm{Pd}(\mathrm{OAc})_{2}(43 \mathrm{mg}$, $180 \mu \mathrm{mol}, 0.1$ equiv.) under an atmosphere of $\mathrm{O}_{2}$ at room temperature for $16 \mathrm{~h}$. The reaction was quenched with saturated $\mathrm{NH}_{4} \mathrm{Cl}$ at $0{ }^{\circ} \mathrm{C}$, the organic layer was separated, and the aqueous phase was extracted two more times with $\mathrm{Et}_{2} \mathrm{O}$. The combined organic phases were dried over $\mathrm{MgSO}_{4}$, filtered and evaporated in vacuo. Chromatography $\left(\mathrm{SiO}_{2}\right.$, cyclohexane / AcOEt 9/1) afforded pure 6 (355 mg, 72\%) as a colorless oil. e.e. $=85 \%$ (determined on Chiral HPLC, Chiralcel OD). $[\alpha]_{D}^{20}=-93\left(C=1.05, \mathrm{CHCl}_{3}\right)$. Litt ${ }^{1}[\alpha]_{D}^{20}=-115.94(C=1.06$, $\left.\mathrm{CHCl}_{3}\right)$.

'H NMR $\left(400 \mathrm{MHz}, \mathrm{CDCl}_{3}\right): 6.83$ (br d, $J=10.0 \mathrm{~Hz}, 1 \mathrm{H}, \mathrm{CH}=\mathrm{CH}$-CHOTBS), 5.92 (d, $J=10.0$ $\mathrm{Hz}, 1 \mathrm{H}, \mathrm{CH}=\mathrm{CH}$-CHOTBS), 4.52 (m, 1H, CHOTBS), 2.57 (dt, $J=16.8,4.5 \mathrm{~Hz}, 1 \mathrm{H}, \mathrm{CHH}-$ $\mathrm{C}=\mathrm{O}$ ), 2.34 (ddd, $J=16.8,12.8,4.8 \mathrm{~Hz}, 1 \mathrm{H}, \mathrm{CH}-\mathrm{C}=\mathrm{O}$ ), 2.19 (m, 1H, CHH-CHOTBS), 2.00 (m, 1H, CHH-CHOTBS), 0.91 (s, 9H, $\left.{ }^{t} \mathrm{BuMe}_{2} \mathrm{Si}\right), 0.12$ (s, 6H, ${ }^{\mathrm{B}} \mathrm{BuMe} \mathrm{e}_{2} \mathrm{Si}$ ).

${ }^{13} \mathrm{C} \mathrm{NMR}\left(100 \mathrm{MHz}, \mathrm{CDCl}_{3}\right): 198.8,153.9,128.7,67.0,35.5,32.9,25.7,18.1,-4.6,-4.8$.

\footnotetext{
${ }_{1}^{1}$ Audia, J.E.; Boisvert, L.; Patten, A.D.; Villalobos, A.; Danishefsky, S.J. J. Org. Chem. 1989, 54, 3738-3740.
} 


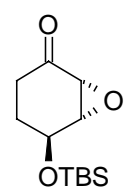

TBHP (5-6 M in decane, $2 \mathrm{~mL}, 10.5 \mathrm{mmol}, 1.3$ equiv.) and Triton $\mathrm{B}(85 \mu \mathrm{L}, 160 \mu \mathrm{mol}, 0.02$ equiv.) were successively added to a solution of $6(1.82 \mathrm{~g}, 8.05 \mathrm{mmol})$ in toluene $(45 \mathrm{~mL})$ at $0{ }^{\circ} \mathrm{C}$. The mixture was stirred at this temperature for $3 \mathrm{~h}$, and the reaction was stopped with $10 \%$ aqueous $\mathrm{Na}_{2} \mathrm{~S}_{2} \mathrm{O}_{3}$. After extraction with cyclohexane, the organic phase was dried over $\mathrm{MgSO}_{4}$ and concentrated in vacuo. Chromatography $\left(\mathrm{SiO}_{2}\right.$, cyclohexane / AcOEt 95/5) afforded 7 as a colorless oil $(1.52 \mathrm{~g}, 78 \%) \cdot[\alpha]_{\mathrm{D}}^{20}=+43\left(C=1.05, \mathrm{CHCl}_{3}\right)$

${ }^{1} \mathrm{H}$ NMR $\left(400 \mathrm{MHz}, \mathrm{CDCl}_{3}\right): 4.44$ (dd, $\left.J=6.6,3.0 \mathrm{~Hz}, 1 \mathrm{H}, \mathrm{CHOTBS}\right), 3.46(\mathrm{t}, J=3.5,1 \mathrm{H}$, CHOTBS-CH-O), 3.26 (d, J = 3.5 Hz, 1H, C=O-CH-O), $2.36\left(\mathrm{~m}, 2 \mathrm{H}, \mathrm{C}=\mathrm{O}-\mathrm{CH}_{2}\right), 2.09(\mathrm{~m}, 1 \mathrm{H}$, CHH-CHOTBS), 1.71 (m, 1H, CHH-CHOTBS), 0.89 (s, 9H, tBu-Si), 0.12 (s, 3H, (CH $\left.\mathrm{CH}_{3}\right) \mathrm{Si}$ ), $0.10\left(\mathrm{~s}, 3 \mathrm{H},\left(\mathrm{CH}_{3}\right) \mathrm{Si}\right)$.

${ }^{13} \mathrm{C}$ NMR $\left(100 \mathrm{MHz}, \mathrm{CDCl}_{3}\right): 204.8,65.3,58.1,55.0,31.6,25.7,25.6,18.1,-4.7,-4.8$.

Anal. calcd for $\mathrm{C}_{12} \mathrm{H}_{22} \mathrm{O}_{3} \mathrm{Si} \mathrm{C:} \mathrm{59.46;} \mathrm{H}: 9.15$ Found C: 59.56; $\mathrm{H}: 9.27$.

(8)

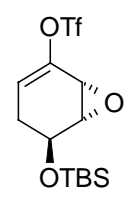

A solution of $7(4.9 \mathrm{~g}, 20.2 \mathrm{mmol})$ in THF $(20 \mathrm{~mL})$ was slowly added to a cold $\left(-78^{\circ} \mathrm{C}\right)$ solution of LiHMDS (prepared from BuLi (13.2 mL, $21.12 \mathrm{mmol}$ ) and HMDS (4.68 mL, $22.2 \mathrm{mmol}$ ) in THF $(20 \mathrm{~mL})$ at $\left.0{ }^{\circ} \mathrm{C}\right)$ at $-78^{\circ} \mathrm{C}$. The mixture was stirred for $15 \mathrm{~min}$, and a solution of $\mathrm{N}$ phenyl-bis-(triflimide) (10.8 g, $30.24 \mathrm{mmol}, 1.5$ equiv.) in THF (20 mL) was added. The mixture was allowed to reach $0^{\circ} \mathrm{C}$, and stirred at this temperature for $16 \mathrm{~h}$. The reaction was stopped with excess saturated $\mathrm{NH}_{4} \mathrm{Cl}$ and extracted three times with $\mathrm{Et}_{2} \mathrm{O}$. The combined organic phases were dried over $\mathrm{MgSO}_{4}$, filtered and concentrated in vacuo. Chromatography $\left(\mathrm{SiO}_{2} 230-400\right.$ mesh, cyclohexane / AcOEt 99/1 $\rightarrow$ 97.5/2.5) afforded impure 8 (yellow solid, $9 \mathrm{~g})$. After evaporation of the liquid phase, the residue was recrystallized $\left(\mathrm{CH}_{2} \mathrm{Cl}_{2} /\right.$ cyclohexane) to afford pure 8 as a slightly yellow oil $(5.7 \mathrm{~g}, 75 \%) .[\alpha]_{\mathrm{D}}{ }^{20}=-11(C=0.9$, $\left.\mathrm{CHCl}_{3}\right)$ 
${ }^{1} \mathrm{H}$ NMR $\left(400 \mathrm{MHz}, \mathrm{CDCl}_{3}\right): 5.77$ (dt, $\left.J=6.0,3.0 \mathrm{~Hz}, 1 \mathrm{H}, \mathrm{CH}=\mathrm{C}\right), 4.40$ (m, 1H, CHOTBS), 3.49 (m, 2H, epoxide), 2.32-2.27 (m, 2H, CH $\mathrm{CH}_{2}, 0.88$ (s, 9H, tBu-Si), $0.11\left(\mathrm{~s}, 3 \mathrm{H},\left(\mathrm{CH}_{3}\right) \mathrm{Si}\right)$, 0.09 (s, 3H, $\left.\left(\mathrm{CH}_{3}\right) \mathrm{Si}\right)$.

${ }^{13} \mathrm{C}$ NMR $\left(100 \mathrm{MHz}, \mathrm{CDCl}_{3}\right): 143.9,118.7\left(\mathrm{q},{ }^{1} \mathrm{~J}_{\mathrm{C}-\mathrm{F}}=319 \mathrm{~Hz}, \mathrm{CF}_{3}\right), 117.4,63.3,56.9,48.6$, 29.4, 25.6, 18.0, $-4.7,-4.8$.

${ }^{19} \mathrm{~F}$ NMR $\left(376 \mathrm{MHz}, \mathrm{CDCl}_{3}\right):-68.42$.

Anal. calcd for $\mathrm{C}_{13} \mathrm{H}_{21} \mathrm{O}_{5} \mathrm{~F}_{3} \mathrm{SSi}$ C: 41.70 ; $\mathrm{H}: 5.65$; F: 15.22 Found C: 42.32; H: 5.97; F: 15.13 .

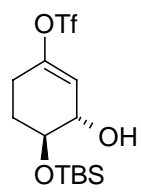

$\mathrm{BH}_{3}$ (1M in THF, $24.5 \mathrm{~mL}, 1.5$ equiv.) was added to a solution of $8(5.7 \mathrm{~g}, 15.2 \mathrm{mmol})$ in THF $(25 \mathrm{~mL})$ at $0{ }^{\circ} \mathrm{C}$. The mixture was stirred for $4 \mathrm{~h}$ at this temperature. The reaction was then stopped with saturated $\mathrm{NH}_{4} \mathrm{Cl}$ and extracted three times with AcOEt. The combined organic phases were dried over $\mathrm{MgSO}_{4}$, filtered and evaporated in vacuo. Chromatography $\left(\mathrm{SiO}_{2}\right.$ 230-400 mesh, cyclohexane / AcOEt 95/5) afforded 9 (colorless oil, $4.6 \mathrm{~g}, 80 \%$ ).

${ }^{1} \mathrm{H}$ NMR $\left(400 \mathrm{MHz}, \mathrm{CDCl}_{3}\right): 5.73(\mathrm{~m}, 1 \mathrm{H}, \mathrm{CH}=\mathrm{C}(\mathrm{OTf})), 4.15$ (br s, $\left.1 \mathrm{H}, \mathrm{CHOH}\right), 3.74(\mathrm{~m}, 1 \mathrm{H}$, CH-OTBS), 2.44 (dt, $J=17.8,6.2 \mathrm{~Hz}, 1 \mathrm{H}, \mathrm{CHH}-\mathrm{C}=\mathrm{C}), 2.37(\mathrm{dm}, J=17.8 \mathrm{~Hz}, 1 \mathrm{H}, \mathrm{CH}-$ $\mathrm{C}=\mathrm{C}$ ), 2.01 (br d, $J=4.3 \mathrm{~Hz}, 1 \mathrm{H}, \mathrm{CH}-\mathrm{OH}), 1.94$ (dtd, $J=13.4,6.0,3.0 \mathrm{~Hz}, 1 \mathrm{H}, \mathrm{CH}$ CHOTBS), 1.81 (m, 1H, CHH-CHOTBS), 0.89 (s, 9H, tBu-Si), $0.10 \& 0.09$ (2 s, 2x3H, $\left.(\mathrm{Me})_{2} \mathrm{Si}\right)$.

${ }^{13} \mathrm{C}$ NMR $\left(100 \mathrm{MHz}, \mathrm{CDCl}_{3}\right): 150.7,118.5\left(\mathrm{q},{ }^{1} \mathrm{~J}_{\mathrm{C}-\mathrm{F}}=319, \mathrm{CF}_{3}\right), 115.4,71.1,70.8,27.0,25.7$, 25.5, 18.0, -4.5, -4.6.

HRMS (FAB) $m / z$ found 319.0282, calcd for $\mathrm{C}_{9} \mathrm{H}_{14} \mathrm{O}_{5} \mathrm{~F}_{3} \mathrm{SSi}\left(\mathrm{M}-\mathrm{C}_{4} \mathrm{H}_{9}\right) \mathrm{m} / z 319.0283$.

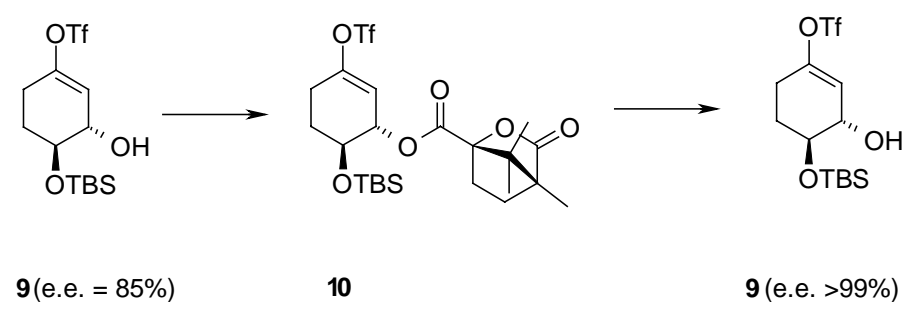


(-)-Camphanyl chloride (972 mg, 4.5 mmol, 1.9 equiv.), DMAP (550 mg, 4.5 mmol, 1.9 equiv.) and $\mathrm{Et}_{3} \mathrm{~N}$ (0.63 mL, $4.5 \mathrm{mmol}, 1.9$ equiv.) were successively added to a solution of 9 (900 mg, $2.39 \mathrm{mmol})$ in THF $(5 \mathrm{~mL})$ at room temperature, and the mixture was stirred for 16 h. The reaction was then stopped with saturated $\mathrm{NH}_{4} \mathrm{Cl}$ and extracted three times with AcOEt. The combined organic phases were dried over $\mathrm{MgSO}_{4}$, filtered and evaporated in vacuo. Chromatography $\left(\mathrm{SiO}_{2} 230-400\right.$ mesh, cyclohexane / AcOEt 98 / 2 $\rightarrow 96$ / 4) afforded pure (1S, 2S) 10 (white solid, $1.04 \mathrm{~g}, 78 \%$ ).

${ }^{1} \mathrm{H}$ NMR $\left(400 \mathrm{MHz}, \mathrm{CDCl}_{3}\right): 5.76(\mathrm{br} \mathrm{d}, J=4.8 \mathrm{~Hz}, 1 \mathrm{H}, \mathrm{CH}=\mathrm{C}(\mathrm{OTf})), 5.20(\mathrm{br} \mathrm{s}, 1 \mathrm{H}, \mathrm{CH}-$ $\mathrm{O}(\mathrm{C}=\mathrm{O})$ ), 3.98 (br s, 1H, CH-OTBS), $2.58(\mathrm{~m}, 1 \mathrm{H}), 2.43$ (ddd, $J=13.4,10.8,4.3 \mathrm{~Hz}, 1 \mathrm{H}$ ), $2.30(\mathrm{dt}, J=17.8,4.3 \mathrm{~Hz}, 1 \mathrm{H}), 1.94(\mathrm{~m}, 4 \mathrm{H}), 1.66(\mathrm{~m}, 1 \mathrm{H}), 1.10$ (s, 3H, Me), $1.02(\mathrm{~s}, 3 \mathrm{H}, \mathrm{Me})$, $0.92(\mathrm{~s}, 3 \mathrm{H}, \mathrm{Me}), 0.86$ (s, 9H, tBu-Si), $0.08 \& 0.09\left(2 \mathrm{~s}, 2 \times 3 \mathrm{H},(\mathrm{Me})_{2} \mathrm{Si}\right)$.

${ }^{13} \mathrm{C}$ NMR $\left(100 \mathrm{MHz}, \mathrm{CDCl}_{3}\right): 178.1,166.8,154.3,118.5$ (q, $\left.{ }^{1} \mathrm{~J}_{\mathrm{C}-\mathrm{F}}=318, \mathrm{CF}_{3}\right), 113.1,90.7$, 72.0, 66.3, 54.8, 54.5, 30.5, 28.8, 26.5, 25.5, 24.0, 17.9, 16.7, 16.6, 9.7, -5.0. Anal. calcd for $\mathrm{C}_{23} \mathrm{H}_{35} \mathrm{O}_{8} \mathrm{~F}_{3} \mathrm{SSi}$ C: 49.63; H: 6.34; F: 10.24 Found C: 49.63; H: 6.52; F: 10.47.

DIBAL (1.5 $\mathrm{M}$ in toluene, $7.5 \mathrm{~mL}, 11.24 \mathrm{mmol}, 6$ equiv.) was added to a solution of $(1 \mathrm{~S}, 2 \mathrm{~S})$ $10(1.04 \mathrm{~g}, 1.87 \mathrm{mmol})$ in THF $(30 \mathrm{~mL})$ at $-78^{\circ} \mathrm{C}$. The mixture was stirred for $16 \mathrm{~h}$ at $-40{ }^{\circ} \mathrm{C}$, and the reaction was then stopped with $\mathrm{MeOH}(5 \mathrm{~mL})$. Addition of brine $(0.2 \mathrm{~mL})$ and $\mathrm{MgSO}_{4}$ $(500 \mathrm{mg}$ ) allowed the formation of a gel which was filtered-off to furnish crude 9 as a yellow oil. Chromatography $\left(\mathrm{SiO}_{2}\right.$, cyclohexane / AcOEt 95/5) afforded enantiomerically pure (1S, 2S) 9 (colorless oil, $480 \mathrm{mg}, 68 \%) \cdot[\alpha]_{\mathrm{D}}^{20}=+33\left(\mathrm{C}=0.94, \mathrm{CHCl}_{3}\right)$. e.e. $>99 \%$ (Chiral HPLC, Chiralcel OD). $m / z=319.0\left(M-\mathrm{C}_{4} \mathrm{H}_{9}\right)$.

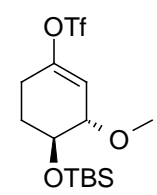

Mel (900 mg, $6.4 \mathrm{mmol}, 5$ equiv.) was added to a mixture of silver oxide $(2.2 \mathrm{~g}, 9.5 \mathrm{mmol}, 7.5$ equiv.), $4 \AA$ molecular sieve ( $800 \mathrm{mg}$ ) and 9 (480 mg, $1.27 \mathrm{mmol})$ in $\mathrm{Et}_{2} \mathrm{O}(10 \mathrm{~mL})$. The suspension was stirred for $3 \mathrm{~h}$ at $40^{\circ} \mathrm{C}$, and the solid was filtered over celite. The solvents were removed in vacuo and the residue was chromatographed $\left(\mathrm{SiO}_{2}\right.$, cyclohexane / $\mathrm{AcOEt}$ $9 / 1)$ to afford 11 as a colorless oil $(480 \mathrm{mg})$.

$[\alpha]_{\mathrm{D}}^{20}=+52\left(c=1.05, \mathrm{CHCl}_{3}\right)$

${ }^{1} \mathrm{H}$ NMR $\left(400 \mathrm{MHz}, \mathrm{CDCl}_{3}\right): 5.78(\mathrm{~d}, J=4.0 \mathrm{~Hz}, 1 \mathrm{H}, \mathrm{CH}=\mathrm{C}), 3.86(\mathrm{~m}, 1 \mathrm{H}, \mathrm{CHOMe}), 3.58(\mathrm{~m}$, 1H, CHOTBS), 3.40 (s, 3H, OMe), 2.50 (dt, $J=17.5,7.1 \mathrm{~Hz}, 1 \mathrm{H}, \mathrm{CH} H-\mathrm{C}=\mathrm{C}$ ), 2.27 (dt, $J=$ 
17.5, $5.3 \mathrm{~Hz}, 1 \mathrm{H}, \mathrm{CH}-\mathrm{C}=\mathrm{C}), 1.90$ (m, 1H, CHH-CHOTBS), 1.79 (m, 1H, CHH-CHOTBS), 0.87 (s, 9H, tBu-Si), 0.08 (s, 3H, $\left.\left(\mathrm{CH}_{3}\right) \mathrm{Si}\right), 0.07$ (s, 3H, $\left.\left(\mathrm{CH}_{3}\right) \mathrm{Si}\right)$.

${ }^{13} \mathrm{C}$ NMR $\left(100 \mathrm{MHz}, \mathrm{CDCl}_{3}\right): 151.9,118.6\left(\mathrm{q},{ }^{1} \mathrm{~J}_{\mathrm{C}-\mathrm{F}}=318 \mathrm{~Hz}, \mathrm{CF}_{3}\right), 115.0,78.9,67.5,57.3$, 26.8, 25.6, 24.5, 18.0, -4.9.

${ }^{19}$ F NMR $\left(376 \mathrm{MHz}, \mathrm{CDCl}_{3}\right):-71.57$.

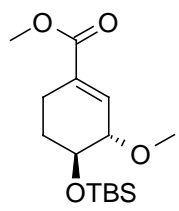

$\mathrm{Pd}(\mathrm{OAc})_{2}$ (28 mg, $0.123 \mathrm{mmol}, 0.1$ equiv.) was added to a mixture of 11 (480 $\mathrm{mg}, 1.23$ mmol), $\mathrm{PPh}_{3}$ (65 mg, $0.246 \mathrm{mmol}, 0.2$ equiv.), $\mathrm{Et}_{3} \mathrm{~N}(342 \mu \mathrm{L}, 2.46 \mathrm{mmol}, 2$ equiv.) and $\mathrm{MeOH}$ (1.5 mL, 49 mmol, 40 equiv.) in DMF (5 mL). The reaction was placed under $\mathrm{CO}$ atmosphere, and the mixture was stirred at room temperature for $16 \mathrm{~h}$. The reaction was then stopped with water and extracted with $\mathrm{Et}_{2} \mathrm{O}$. The combined organic phases were dried over $\mathrm{MgSO}_{4}$, filtered and evaporated in vacuo. Chromatography $\left(\mathrm{SiO}_{2}\right.$, cyclohexane / AcOEt 95/5) afforded pure 12 (colorless oil, $322 \mathrm{mg}, 83 \%$ (from 9)). $[\alpha]_{\mathrm{D}}^{20}=+54\left(c=1.5, \mathrm{CHCl}_{3}\right.$ ).

${ }^{1} \mathrm{H}$ NMR $\left(400 \mathrm{MHz}, \mathrm{CDCl}_{3}\right): 6.82$ (br s, $\left.1 \mathrm{H}, \mathrm{CH}=\mathrm{C}\right), 3.79$ (m, 1H, CHOTBS), 3.74 (s, 3H, $\mathrm{CO}_{2} \mathrm{Me}$ ), $3.64(\mathrm{~m}, 1 \mathrm{H}, \mathrm{CHOMe}), 3.47(\mathrm{~s}, 3 \mathrm{H}, \mathrm{OMe}), 2.39-2.29\left(\mathrm{~m}, 2 \mathrm{H}, \mathrm{CH}_{2}-\mathrm{C}=\mathrm{CH}\right), 1.85-1.56$ (m, 2H, CH $\mathrm{H}_{2}$-CHOTBS), 0.89 (s, 9H, tBu-Si), 0.09 (s, 3H, Me-Si), 0.08 (s, 3H, Me-Si).

${ }^{13} \mathrm{C} \mathrm{NMR}\left(100 \mathrm{MHz}, \mathrm{CDCl}_{3}\right): 167.3,135.6,132.0,80.8,70.2,57.8,51.7,28.7,25.8,22.7$, 18.1, - -4.7.

Anal. calcd for $\mathrm{C}_{15} \mathrm{H}_{28} \mathrm{O}_{4} \mathrm{Si}$ C: $59.96 ; \mathrm{H}: 9.39$ Found C: 59.86; H: 9.54.

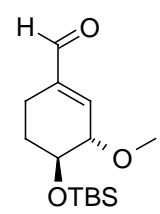

DIBAL (2.78 mL, 1.5M in toluene, $4.17 \mathrm{mmol}, 3$ equiv.) was added to a solution of 12 (410 $\mathrm{mg}, 1.36 \mathrm{mmol})$ in THF $(5 \mathrm{~mL})$ at $-78^{\circ} \mathrm{C}$. The mixture was stirred for $2 \mathrm{~h}$ at this temperature and the reaction was then stopped with $\mathrm{MeOH}(0.5 \mathrm{~mL})$. Addition of brine $(0.5 \mathrm{~mL})$ and $\mathrm{MgSO}_{4}(100 \mathrm{mg})$ allowed the formation of a gel which was filtered-off to provide a crude allylic alcohol as a colorless oil (330 mg).

To a solution of the above allylic alcohol (134 mg, $0.492 \mathrm{mmol})$ in $\mathrm{CH}_{2} \mathrm{Cl}_{2}(3 \mathrm{~mL})$ was added Dess Martin periodinane (1.4 mL, $15 \%$ solution in $\mathrm{CH}_{2} \mathrm{Cl}_{2}, 1.5$ equiv.). The resulting mixture was stirred for $2 \mathrm{~h}$ at room temperature, and the reaction was stopped by saturated $\mathrm{NaHCO}_{3}$ 
and $10 \%$ aqueous $\mathrm{Na}_{2} \mathrm{~S}_{2} \mathrm{O}_{3}(1 / 1)$. The two phase-mixture was vigorously stirred at room temperature for $1 \mathrm{~h}$. After extraction with $\mathrm{CH}_{2} \mathrm{Cl}_{2}$, the organic phase was dried over $\mathrm{MgSO}_{4}$, filtered and concentrated in vacuo. Chromatography $\left(\mathrm{SiO}_{2}\right.$, cyclohexane / AcOEt 9/1) afforded pure 13 (colorless oil, $130 \mathrm{mg}, 83 \%) .[\alpha]_{\mathrm{D}}^{20}=+74\left(\mathrm{C}=1.2, \mathrm{CHCl}_{3}\right)$

${ }^{1} \mathrm{H}$ NMR $\left(400 \mathrm{MHz}, \mathrm{CDCl}_{3}\right): 9.49$ (s, $\left.1 \mathrm{H}, \mathrm{H}-\mathrm{C}=\mathrm{O}\right), 6.63$ (br s, $\left.1 \mathrm{H}, \mathrm{CH}=\mathrm{C}\right), 3.85$ (ddd, $J=8.8$, 6.0, 3.6, 1H, CHOTBS), 3.76 (m, 1H, CHOMe), 3.53 (s, 3H, OMe), 2.55 (dt, J=18.4, $5.6 \mathrm{~Hz}$, $1 \mathrm{H}, \mathrm{CH}-\mathrm{C}=\mathrm{CH}), 2.18(\mathrm{dm}, J=18.4,1 \mathrm{H}, \mathrm{CH}-\mathrm{C}=\mathrm{CH}), 1.86-1.56\left(\mathrm{~m}, 2 \mathrm{H}, \mathrm{CH}_{2}-\mathrm{CHOTBS}\right)$, 0.89 (s, 9H, tBu), 0.10 (s, 3H, MeSi), 0.09 (s, 3H, MeSi).

${ }^{13} \mathrm{C}$ NMR $\left(100 \mathrm{MHz}, \mathrm{CDCl}_{3}\right): 193.7,145.6,142.1,80.9,70.6,58.3,28.0,25.8,19.5,18.1$, 4.7 .

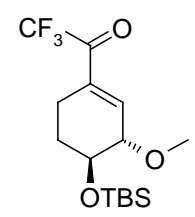

$\mathrm{CF}_{3} \mathrm{SiMe}_{3}(138 \mu \mathrm{L}, 1.6 \mathrm{mmol}, 1.5$ equiv.) and TBAF (1M in THF, $100 \mu \mathrm{L}, 0.1$ equiv.) were added to a solution of $13(290 \mathrm{mg}, 1.07 \mathrm{mmol})$ in THF $(10 \mathrm{~mL})$ at $0{ }^{\circ} \mathrm{C}$ and the mixture was stirred for $1 \mathrm{~h}$ at this temperature. The reaction was stopped with saturated $\mathrm{NH}_{4} \mathrm{Cl}$ and extracted with ethyl acetate. The combined organic phases were dried over $\mathrm{MgSO}_{4}$, filtered and concentrated in vacuo. The residue was dissolved in a mixture of THF $(4 \mathrm{~mL}) / \mathrm{H}_{2} \mathrm{O}(0.4$ $\mathrm{mL}$ ) and treated with TFA (16 $\mu \mathrm{L}, 0.2$ equiv.). The mixture was stirred for $6 \mathrm{~h}$ at $0{ }^{\circ} \mathrm{C}$, and the reaction was carefully stopped with saturated $\mathrm{NaHCO}_{3}$. After extraction with ethyl acetate, the combined organic phases were dried over $\mathrm{MgSO}_{4}$, filtered and concentrated in vacuo. The residue was dissolved in $\mathrm{CH}_{2} \mathrm{Cl}_{2}(6 \mathrm{~mL})$ and treated with Dess Martin periodinane $(15 \%$ in $\mathrm{CH}_{2} \mathrm{Cl}_{2}, 2.7 \mathrm{~mL}, 1.3 \mathrm{mmol}, 1.2$ equiv.) at $0{ }^{\circ} \mathrm{C}$. The mixture was stirred for $16 \mathrm{~h}$ at this temperature, and the reaction was stopped with saturated $\mathrm{NaHCO}_{3}$ and $10 \% \mathrm{Na}_{2} \mathrm{~S}_{2} \mathrm{O}_{3}$ at 0 ${ }^{\circ} \mathrm{C}$. The mixture was vigorously stirred for $1 \mathrm{~h}$ at this temperature, and then extracted with $\mathrm{CH}_{2} \mathrm{Cl}_{2}$. The combined organic phases were dried over $\mathrm{MgSO}_{4}$, filtered and concentrated in vacuo. Chromatography $\left(\mathrm{SiO}_{2}\right.$, cyclohexane / AcOEt 9/1) afforded pure 14 as a colorless oil (200 mg, 55\%). $[\alpha]_{D}^{20}=-8\left(C=0.5, \mathrm{CHCl}_{3}\right)$

${ }^{1} \mathrm{H}$ NMR $\left(400 \mathrm{MHz}, \mathrm{CDCl}_{3}\right): 6.96$ (br s, $\left.1 \mathrm{H}, \mathrm{CH}=\mathrm{C}\right), 3.84$ (ddd, $J=9.2,6.0,3.2 \mathrm{~Hz}, 1 \mathrm{H}$, CHOTBS), 3.75 (br s, 1H, CHOMe), 3.52 (s, 3H, OMe), 2.45 (dt, J=18.5, 5.4 Hz, 1H, CHH$\mathrm{C}=\mathrm{CH}), 2.30(\mathrm{dm}, J=18.5,1 \mathrm{H}, \mathrm{CH}-\mathrm{C}=\mathrm{CH}), 1.89-1.58\left(\mathrm{~m}, 2 \mathrm{H}, \mathrm{CH}_{2}-\mathrm{CHOTBS}\right), 0.89$ (s, 9H, tBu), 0.10 (s, 3H, MeSi), 0.09 (s, 3H, MeSi).

${ }^{13} \mathrm{C}$ NMR $\left(100 \mathrm{MHz}, \mathrm{CDCl}_{3}\right): 181.0\left(\mathrm{q},{ }^{2} \mathrm{~J}_{\mathrm{C}-\mathrm{F}}=34 \mathrm{~Hz},(\mathrm{C}=\mathrm{O})-\mathrm{CF}_{3}\right), 143.0,134.0,116.3\left(\mathrm{q},{ }^{1} \mathrm{~J}_{\mathrm{C}-}\right.$ $\left.\mathrm{F}=290 \mathrm{~Hz}, \mathrm{CF}_{3}\right), 80.7,69.7,58.4,29.7,28.0,25.7,21.6,18.0,-4.7$.

${ }^{19} \mathrm{~F}$ NMR $\left(376 \mathrm{MHz}, \mathrm{CDCl}_{3}\right):-70.68$. 
HRMS (FAB) $m / z$ found 281.0827, calcd for $\mathrm{C}_{11} \mathrm{H}_{16} \mathrm{~F}_{3} \mathrm{O}_{3} \mathrm{Si}\left(\mathrm{M}-\mathrm{C}_{4} \mathrm{H}_{9}\right) \mathrm{m} / \mathrm{z} 281.0821$.

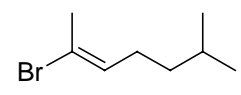

BuLi (29.6 mL, $47.4 \mathrm{mmol}, 2$ equiv.) was slowly added to a solution of 2,4,6- trisylhydrazone $15(8.0 \mathrm{~g}, 23.7 \mathrm{mmol})$ in DME $(70 \mathrm{~mL})$ at $-78^{\circ} \mathrm{C}$. The resulting orange solution was stirred for $10 \mathrm{~min}$ at $-60^{\circ} \mathrm{C}$, cooled at $-78^{\circ} \mathrm{C}$ and 1 -iodo-3-methylbutane $(3.13 \mathrm{~mL}, 23.7 \mathrm{mmol}, 1$ equiv.) was added dropwise. The resulting mixture was stirred for $16 \mathrm{~h}$ at $-40{ }^{\circ} \mathrm{C}$. The white suspension obtained was cooled at $-78^{\circ} \mathrm{C}$, and TMEDA (12.5 mL, $82.3 \mathrm{mmol}, 3.5$ equiv.) and BuLi (16.3 mL, $26.1 \mathrm{mmol}, 1.1$ equiv.) were successively added. This orange mixture was stirred for $20 \mathrm{~min}$ at $-78{ }^{\circ} \mathrm{C}$, and then allowed to reach $0{ }^{\circ} \mathrm{C}$ for a few minutes, until gas evolution was complete. The mixture was cooled at $-78{ }^{\circ} \mathrm{C}, 1$,2-dibromoethane $(6.6 \mathrm{~mL}, 35.5$ mmol, 1.5 equiv.) was added and the mixture was gradually allowed to reach $0{ }^{\circ} \mathrm{C}$. The reaction was stopped with brine and extracted with $\mathrm{Et}_{2} \mathrm{O}$. The combined organic phases were washed with water and then with brine, dried over $\mathrm{MgSO}_{4}$ and concentrated in vacuo. Chromatography $\left(\mathrm{SiO}_{2}\right.$, cyclohexane) afforded pure bromide 16 (oil, $2.5 \mathrm{~g}, 57 \%$ ).

${ }^{1} \mathbf{H}$ NMR (400 MHz, $\mathrm{CDCl}_{3}$ ) : 5.82 (t, $J=7.5 \mathrm{~Hz}, 1 \mathrm{H}, \mathrm{CH}_{2}-\mathrm{CH}=\mathrm{C}$ ), 2.21 (s, 3H, Me), 2.00 (q, J $\left.=7.5,2 \mathrm{H}, \mathrm{CH}_{2}-\mathrm{CH}=\mathrm{C}\right), 1.54\left(\mathrm{~m}, 1 \mathrm{H}, \mathrm{CH}(\mathrm{Me})_{2}\right), 1.25$ (q, J = $\left.7.5 \mathrm{~Hz}, 2 \mathrm{H}, \mathrm{CH}_{2}-\mathrm{CH}(\mathrm{Me})_{2}\right), 0.88$ $\left(\mathrm{d}, J=7.0 \mathrm{~Hz}, 6 \mathrm{H},\left(\mathrm{CH}_{3}\right)_{2} \mathrm{CH}\right)$.

${ }^{13} \mathrm{C}$ NMR $\left(100 \mathrm{MHz}, \mathrm{CDCl}_{3}\right): 132.6(\mathrm{C}=\mathrm{CH}), 118.9(\mathrm{C}=\mathrm{C}), 38.1\left(\mathrm{CH}_{2} \mathrm{CH}(\mathrm{Me})_{2}\right), 27.5$ $\left(\mathrm{CH}(\mathrm{Me})_{2}\right), 27.4\left(\mathrm{CH}_{3}-\mathrm{C}=\mathrm{C}\right), 23.1\left(\mathrm{C}=\mathrm{C}-\mathrm{CH}_{2}\right), 22.4\left(\mathrm{CH}\left(\mathrm{CH}_{3}\right)_{2}\right)$.

HRMS (FAB) $m / z$ found 190.0362 , calcd for $\mathrm{C}_{8} \mathrm{H}_{15} \mathrm{Br} \mathrm{m} / \mathrm{z} 190.0357$.

\section{Preparation of 17:}

\section{a. Preparation of vinyl triflate $A$}

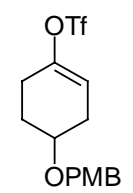

A solution of 4-(4-methoxy-benzyloxy)-cyclohexanone $(900 \mathrm{mg}, 3.8 \mathrm{mmol})$ in THF $(3 \mathrm{~mL})$ was added to a cold $\left(-78{ }^{\circ} \mathrm{C}\right)$ solution of LDA ( $4.2 \mathrm{mmol}, 1.1$ equiv.) in THF ( $\left.3 \mathrm{~mL}\right)$. After stirring for $15 \mathrm{~min}$, a solution of $\mathrm{N}$-phenyl-bis-trifluoromethanesulfonimide $(1.75 \mathrm{~g}, 4.95 \mathrm{mmol}$, 1.3 equiv.) in THF ( $3 \mathrm{~mL}$ ) was added. The mixture was warmed to $0^{\circ} \mathrm{C}$ and stirred for $48 \mathrm{~h}$. The reaction was stopped by addition of saturated $\mathrm{NH}_{4} \mathrm{Cl}$ and extracted with ether. The 
organic phases were dried, concentrated in vacuo and the residue was chromatographed $\left(\mathrm{SiO}_{2}\right.$, cyclohexane / AcOEt 9/1) to afford a colorless oil (1.11g).

NMR ${ }^{1} \mathrm{H}\left(400 \mathrm{MHz}, \mathrm{CDCl}_{3}\right): 7.25 \& 6.88(2 \mathrm{~d}, J=8.4 \mathrm{~Hz}, 4 \mathrm{H}, \mathrm{ArH}), 5.65(\mathrm{br} \mathrm{s}, 1 \mathrm{H}, \mathrm{C}=\mathrm{CH})$, 4.49 (m, 2H, $\mathrm{CH}_{2}-\mathrm{Ar}$ ), 3.80 (s, 3H, OMe), 3.69 (m, 1H, CH-OPMB), 2.50-2.26 (m, 4H), 1.98$1.91(\mathrm{~m}, 2 \mathrm{H})$.

b. Preparation of 4-(4-methoxy-benzyloxy)-cyclohex-1-enecarboxylic acid methyl ester (B)

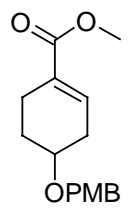

$\mathrm{Pd}(\mathrm{OAc})_{2}$ (22.4 mg, $0.10 \mathrm{mmol}, 0.1$ equiv.), was added to a solution of triflate $\mathrm{A}$ (400 $\mathrm{mg}$, $1.09 \mathrm{mmol}$ ), $\mathrm{PPh}_{3}$ (52 mg, $0.20 \mathrm{mmol}, 0.2$ equiv.), $\mathrm{Et}_{3} \mathrm{~N}(279 \mu \mathrm{L}, 2.0 \mathrm{mmol}, 2$ equiv.) and $\mathrm{MeOH}$ (1.7 mL, $40 \mathrm{mmol}, 40$ equiv.) in DMF (5 mL). The mixture was degassed, placed under $\mathrm{CO}$ atmosphere (1 atm.) and stirred for $16 \mathrm{~h}$. The reaction was stopped by adding water and extracted with $\mathrm{H}_{2} \mathrm{O}$. The organic layer was dried, the solvents evaporated and the residue was chromatographed $\left(\mathrm{SiO}_{2}\right.$, cyclohexane / AcOEt 9/1), to furnish $\mathrm{B}(300 \mathrm{mg})$.

$\mathbf{R M N}^{1} \mathbf{H}\left(400 \mathrm{MHz}, \mathrm{CDCl}_{3}\right): 7.26 \& 6.86(2 \mathrm{~d}, J=8.4 \mathrm{~Hz}, 4 \mathrm{H}, \operatorname{Ar} H), 6.86(1 \mathrm{H}, \mathrm{C}=\mathrm{CH}), 3.80$ (s, 3H, OMe), 3.72 (s, 3H, OMe), $3.68(\mathrm{~m}, 1 \mathrm{H}, \mathrm{CH}-\mathrm{OPMB}), 2.51(\mathrm{~m}, 2 \mathrm{H}), 2.27(\mathrm{~m}, 2 \mathrm{H}), 1.95$ $(\mathrm{m}, 1 \mathrm{H}), 1.75(\mathrm{~m}, 1 \mathrm{H})$.

c. Preparation of 4-(4-methoxy-benzyloxy)-cyclohex-1-enecarboxaldehyde (C)

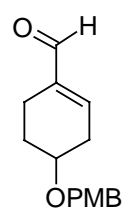

At $-78^{\circ} \mathrm{C}$, DIBAL $\left(870 \mu \mathrm{L}, 1.5 \mathrm{M}\right.$ in toluene, 1.8 equiv.) was added to a cold $\left(-78^{\circ} \mathrm{C}\right)$ solution of ester $\mathrm{B}(200 \mathrm{mg}, 0.72 \mathrm{mmol})$ in $\mathrm{CH}_{2} \mathrm{Cl}_{2}(4 \mathrm{~mL})$. The solution was stirred for $3 \mathrm{~h}$ at $-78{ }^{\circ} \mathrm{C}$. then $\mathrm{MeOH}(0.5 \mathrm{~mL})$ was added followed by brine $(0.5 \mathrm{~mL}), \mathrm{MgSO}_{4}(100 \mathrm{mg})$ and AcOEt (10 $\mathrm{mL}$ ). The mixture was allowed to warm to r.t. and the gel thus obtained was filtered over a pad of celite. The filtrate was evaporated and the resulting allylic alcohol (330 $\mathrm{mg}$ ) was dissolved in $\mathrm{CH}_{2} \mathrm{Cl}_{2}(10 \mathrm{~mL})$. Dess-Martin periodinane (1.8 $\mathrm{mL}, 15 \%$ in $\mathrm{CH}_{2} \mathrm{Cl}_{2}, 1.3$ equiv.) was added and the mixture was stirred for $1 \mathrm{~h}$. Saturated solutions of $\mathrm{NaHCO}_{3}$ and $\mathrm{Na}_{2} \mathrm{~S}_{2} \mathrm{O}_{3}$ were successively added and stirring was continued for $1 \mathrm{~h}$. Extraction with $\mathrm{CH}_{2} \mathrm{Cl}_{2}$, 
evaporation of the solvents and chromatography $\left(\mathrm{SiO}_{2}\right.$, cyclohexane / AcOEt 8/2), afforded the desired aldehyde (150 mg).

$\mathbf{R M N}^{1} \mathbf{H}\left(400 \mathrm{MHz}, \mathrm{CDCl}_{3}\right): 9.42(\mathrm{~s}, 1 \mathrm{H}, \mathrm{CHO}), 7.27 \& 6.87(2 \mathrm{~d}, J=8.8 \mathrm{~Hz}, 4 \mathrm{H}, \operatorname{ArH}), 6.69$ (br s, $1 \mathrm{H}, \mathrm{C}=\mathrm{CH}), 4.56$ \& $4.47\left(2 \mathrm{~d}, J=11.9 \mathrm{~Hz}, 2 \mathrm{H}, \mathrm{CH}_{2}-\mathrm{Ar}\right), 3.80(\mathrm{~s}, 3 \mathrm{H}, \mathrm{OMe}), 3.75(\mathrm{~m}$, 1H, CH-OPMB), 2.62 (br d, $J=16.0 \mathrm{~Hz}, 1 \mathrm{H}), 2.42(\mathrm{~m}, 2 \mathrm{H}), 2.20(\mathrm{~m}, 1 \mathrm{H}), 1.90(\mathrm{~m}, 1 \mathrm{H}), 1.78$ $(\mathrm{m}, 1 \mathrm{H})$.

\section{d. Preparation of Trifluoromethyl ketone 17}<smiles>O=C(C1CCC(O[18OH])CC1)C(F)(F)F</smiles>

To a cool $\left(0^{\circ} \mathrm{C}\right)$ solution of aldehyde $\mathrm{C}(27 \mathrm{mg}, 110 \mu \mathrm{mol})$ and $\mathrm{CF}_{3} \mathrm{TMS}(25 \mu \mathrm{L}, 160 \mu \mathrm{mol}, 1.5$ equiv.) in THF ( $1 \mathrm{~mL}$ ) was added TBAF (10 $\mu \mathrm{L}, 1 \mathrm{M}$ in THF, 0.1 equiv.). The mixture was stirred for $1 \mathrm{~h}$ and aqueous $\mathrm{HCl}(1 \mathrm{M})$ was added. Stirring was continued for $30 \mathrm{~min}$ and the mixture was extracted with AcOEt. The residue obtained after evaporation of the solvents was dissolved in $\mathrm{CH}_{2} \mathrm{Cl}_{2}(1 \mathrm{~mL})$ and Dess-Martin periodinane $\left(250 \mu \mathrm{L}, 15 \%\right.$ in $\mathrm{CH}_{2} \mathrm{Cl}_{2}, 130$ $\mu$ mol, $1.3 \mathrm{eq}$ ) was added. After stirring for $3 \mathrm{~h}$, saturated solutions of $\mathrm{NaHCO}_{3}$ and $\mathrm{Na}_{2} \mathrm{~S}_{2} \mathrm{O}_{3}$ were successively added and stirring was continued for $1 \mathrm{~h}$. Extraction with $\mathrm{CH}_{2} \mathrm{Cl}_{2}$, evaporation of the solvents and chromatography $\left(\mathrm{SiO}_{2}\right.$, cyclohexane / AcOEt 8/2), afforded 17 (24 mg).

$\mathbf{R M N}^{1} \mathbf{H}\left(400 \mathrm{MHz}, \mathrm{CDCl}_{3}\right): 7.27 \& 6.88(2 \mathrm{~d}, J=8.4,4 \mathrm{H}, \mathrm{ArH}), 7.10(\mathrm{br} \mathrm{s}, 1 \mathrm{H}, \mathrm{C}=\mathrm{CH}), 4.56$ \& 4.47 (2 d, $\left.J=11.6,2 \mathrm{H}, \mathrm{CH}_{2}-\mathrm{Ar}\right), 3.80$ (s, 3H, OMe), 3.74 (m, 1H, CH-OPMB), 2.65 (br d, J $=20.0,1 \mathrm{H}), 2.50(\mathrm{~m}, 2 \mathrm{H}), 2.30(\mathrm{~m}, 1 \mathrm{H}), 1.92(\mathrm{~m}, 1 \mathrm{H}), 1.84(\mathrm{~m}, 1 \mathrm{H})$.

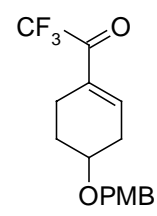

17

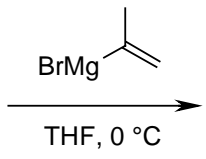

$\mathrm{THF}, 0^{\circ} \mathrm{C}$

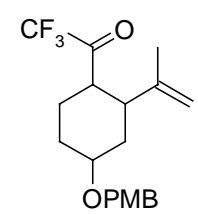

18

Isoprenyl magnesium bromide ( $0.5 \mathrm{M}$ in THF, $300 \mu \mathrm{L}, 0.150 \mathrm{mmol}, 2$ equiv.) was added at 0 ${ }^{\circ} \mathrm{C}$ to a solution of 17 (24 mg, $\left.0.076 \mathrm{mmol}\right)$ in THF $(1 \mathrm{~mL})$. The mixture was stirred for $1.5 \mathrm{~h}$ at $0{ }^{\circ} \mathrm{C}$, then the reaction was stopped with saturated $\mathrm{NH}_{4} \mathrm{Cl}$ and extracted with AcOEt. The 
combined organic phases were dried over $\mathrm{MgSO}_{4}$ and concentrated in vacuo. Chromatography on preparative $\mathrm{SiO}_{2}$ plates (cyclohexane / AcOEt 8/2) afforded 18 (11 mg, $40 \%)$.

${ }^{1} \mathrm{H}$ NMR $\left(400 \mathrm{MHz}, \mathrm{CDCl}_{3}\right): 7.26 \& 6.88(2 \mathrm{~d}, \mathrm{AB}, J=8.4 \mathrm{~Hz}, 4 \mathrm{H}, \mathrm{ArH}), 4.82(\mathrm{~s}, 1 \mathrm{H}$, $\mathrm{C}=\mathrm{CH}$ ), 4.66 (s, 1H, C=CHH), 4.43 (s, 2H, CH$-\mathrm{Ar}$ ), 3.84 (br s, 1H, CH-OPMB), 3.80 (s, 3H, OMe), 3.49 (br s, 1H, CH-C=O), 2.68 (br d, $J=13.5 \mathrm{~Hz}, 1 \mathrm{H}, \mathrm{CH}-\mathrm{C}(\mathrm{Me})=\mathrm{CH}_{2}$ ), 2.26 (td, $J=$ 13.5, $\left.2.4 \mathrm{~Hz}, 1 \mathrm{H}, \mathrm{CHH}-\mathrm{CH}-\mathrm{C}(\mathrm{Me})=\mathrm{CH}_{2}\right), 2.20(\mathrm{dm}, J=13.6,1 \mathrm{H}, \mathrm{CH}-\mathrm{CH}-\mathrm{C}=\mathrm{O}), 1.85(\mathrm{~m}$, $3 \mathrm{H}), 1.73\left(\mathrm{~s}, 3 \mathrm{H}, \mathrm{CH}_{3}\right), 1.62\left(\mathrm{dm}, J=14.0 \mathrm{~Hz}, 1 \mathrm{H}, \mathrm{CH}_{2}-\mathrm{CH} H-\mathrm{CH}(\mathrm{OPMB})\right.$ ).

(19) \& (20)

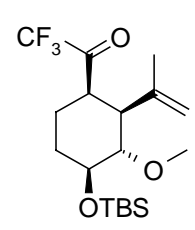

19

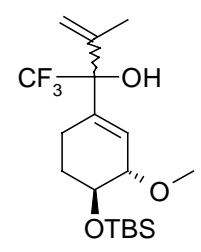

20

Isoprenyl magnesium bromide ( $0.5 \mathrm{M}$ in THF, $350 \mu \mathrm{L}, 0.175 \mathrm{mmol}, 2$ equiv.) was added at 0 ${ }^{\circ} \mathrm{C}$ to a solution of 14 (30 mg, $\left.0.089 \mathrm{mmol}\right)$ in THF $(0.5 \mathrm{~mL})$. The mixture was stirred for $2 \mathrm{~h}$ at $0{ }^{\circ} \mathrm{C}$, the reaction was stopped with saturated $\mathrm{NH}_{4} \mathrm{Cl}$ and extracted with AcOEt. The combined organic phases were dried over $\mathrm{MgSO}_{4}$ and concentrated in vacuo. Chromatography on preparative $\mathrm{SiO}_{2}$ plates (cyclohexane / AcOEt 9/1) afforded pure 19 (1 $\mathrm{mg}$ ) as well as two fractions corresponding to both diastereomers of 20 (4 mg each).

(20, one representative isomer) ${ }^{1} \mathrm{H}$ NMR $\left(400 \mathrm{MHz} \mathrm{CDCl}_{3}\right) 6.03(\mathrm{~s}, 1 \mathrm{H}, \mathrm{C}=\mathrm{CH}), 5.29(\mathrm{~s}, 1 \mathrm{H}$, $\mathrm{C}=\mathrm{CH} H$ ), $5.18(\mathrm{~s}, 1 \mathrm{H}, \mathrm{C}=\mathrm{CHH}), 3.80(\mathrm{~m}, 1 \mathrm{H}, \mathrm{CH}$-OTBS), $3.62(\mathrm{br} \mathrm{s}, 1 \mathrm{H}, \mathrm{CH}-\mathrm{OMe}), 3.44(\mathrm{~s}$, 3H, OMe), 2.29 (s, 1H, OH), 2.12 (dt, J = 17.0, $5.6 \mathrm{~Hz}, 1 \mathrm{H}, \mathrm{CHH}-\mathrm{CH}(\mathrm{OTBS})), 2.05(\mathrm{~m}, 1 \mathrm{H}$, $\mathrm{CH}-\mathrm{CH}(\mathrm{OTBS})), 1.78(\mathrm{~m}, 1 \mathrm{H}, \mathrm{CH}-\mathrm{C}=\mathrm{CH}), 1.77(\mathrm{~s}, 3 \mathrm{H}, \mathrm{Me}), 1.64(\mathrm{~m}, 1 \mathrm{H}, \mathrm{CH}-\mathrm{C}=\mathrm{CH})$, $0.88\left(\mathrm{~s}, 9 \mathrm{H},{ }^{\mathrm{t}} \mathrm{Bu}\right), 0.09 \& 0.08\left(2 \mathrm{~s}, 6 \mathrm{H}, \mathrm{Me}_{2} \mathrm{Si}\right)$.

(19) ${ }^{1} \mathrm{H}$ NMR $\left(400 \mathrm{MHz}, \mathrm{CDCl}_{3}\right) 4.93(\mathrm{~s}, 1 \mathrm{H}, \mathrm{C}=\mathrm{CH} H), 4.76(\mathrm{~s}, 1 \mathrm{H}, \mathrm{C}=\mathrm{CHH}), 3.80$ (dd, $J=$ 10.4, 8.0 Hz, 1H, CH-OMe), 3.53 (s, 3H, OMe), 3.53 (m, 1H, CH-OTBS), 3.45 (m, 1H, CH$\mathrm{C}=\mathrm{O}), 2.24\left(\mathrm{dd}, J=10.4,4.8 \mathrm{~Hz}, 1 \mathrm{H}, \mathrm{CH}-\mathrm{C}(\mathrm{Me})=\mathrm{CH}_{2}\right), 1.86(\mathrm{~m}, 1 \mathrm{H}), 1.76(\mathrm{~s}, 3 \mathrm{H}, \mathrm{Me}), 1.75-$ $1.60(\mathrm{~m}, 3 \mathrm{H}), 0.90\left(\mathrm{~s}, 9 \mathrm{H},{ }^{\mathrm{t}} \mathrm{Bu}\right), 0.10 \& 0.07\left(2 \mathrm{~s}, 6 \mathrm{H}, \mathrm{Me}_{2} \mathrm{Si}\right)$. 


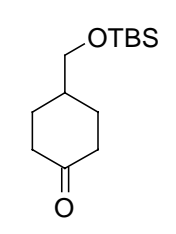

TBSCl (640 mg, $4.3 \mathrm{mmol}$ ), imidazole $(540 \mathrm{mg}, 7.8 \mathrm{mmol}$ ) and a catalytic amount of DMF were added to a solution of alcohol 4-hydroxymethyl-cyclohexanone $(\mathbf{2 1}, 500 \mathrm{mg}, 3.9 \mathrm{mmol})$ in THF $(10 \mathrm{~mL})$ at room temperature. The mixture was stirred for $2 \mathrm{~h}$, then the reaction was stopped with saturated $\mathrm{NH}_{4} \mathrm{Cl}$ and extracted with cyclohexane. The combined organic phases were dried over $\mathrm{MgSO}_{4}$ and concentrated in vacuo. Chromatography $\left(\mathrm{SiO}_{2}\right.$, cyclohexane / AcOEt 95/5) afforded pure 22 as a colorless oil (700 mg, 75\%)

${ }^{1} \mathrm{H}$ NMR (400 MHz, CDCl $): 3.50$ (d, J = 6.3 Hz, 2H, CH $\mathrm{CHTS}_{2}$ ), 2.45-2.25 (m, 4H), 2.05 (m, $2 \mathrm{H}), 1.90(\mathrm{~m}, 1 \mathrm{H}), 1.42(\mathrm{~m}, 2 \mathrm{H}), 0.89(\mathrm{~s}, 9 \mathrm{H}, \mathrm{tBu}), 0.04\left(\mathrm{~s}, 6 \mathrm{H},(\mathrm{Me})_{2} \mathrm{Si}\right)$.

${ }^{13} \mathrm{C}$ NMR $\left(100 \mathrm{MHz}, \mathrm{CDCl}_{3}\right): 212.2,67.0,40.5,38.7,29.2,25.9,18.3,-5.4$

Anal. calcd for $\mathrm{C}_{13} \mathrm{H}_{26} \mathrm{O}_{2} \mathrm{Si}$ : C, 64.41; $\mathrm{H}, 10.81$ Found: $\mathrm{C}, 64.12 ; \mathrm{H}, 10.92$.

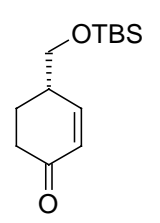

BuLi (12 mL, $19.2 \mathrm{mmol}, 2.3$ equiv.) was added to a suspension of (+)-bis $(\alpha-$ methylbenzylamine) hydrochloride $\left(2.5 \mathrm{~g}, 9.6 \mathrm{mmol}, 1.15\right.$ equiv.) in THF $(30 \mathrm{~mL})$ at $-78{ }^{\circ} \mathrm{C}$. The mixture was stirred at this temperature for $10 \mathrm{~min}$, and then at $0^{\circ} \mathrm{C}$ for $5 \mathrm{~min}$. The yellow solution thus obtained was cooled to $-100{ }^{\circ} \mathrm{C}\left(\mathrm{MeOH} /\right.$ liquid $\mathrm{N}_{2}$ ) and $\mathrm{Me}_{3} \mathrm{SiCl}(4.2 \mathrm{~mL}, 33$ mmol, 4 equiv.) was added, followed by a solution of $22(2 \mathrm{~g}, 8.25 \mathrm{mmol})$ in THF $(10 \mathrm{~mL})$. The mixture was stirred for $2 \mathrm{~h}$ while keeping the temperature between -100 and $-95^{\circ} \mathrm{C}$. $\mathrm{Et}_{3} \mathrm{~N}$ $(15 \mathrm{~mL})$ was then added and the solution was transferred via cannula to cool $\left(0^{\circ} \mathrm{C}\right)$ water. The two phases were separated, and the aqueous phase was extracted two times with AcOEt. The combined organic phases were dried over $\mathrm{MgSO}_{4}$, filtered and evaporated in vacuo. The residue was filtered over a short pad of silica gel (cyclohexane / $\mathrm{AcOEt} / \mathrm{Et}_{3} \mathrm{~N}$ $97.5 / 2.5 / 1)$ to remove the free amine. The silyl enol ether thus obtained ( $2 \mathrm{~g}$ ) was dissolved in DMSO $(100 \mathrm{~mL})$ and treated with $\mathrm{Pd}(\mathrm{OAc})_{2}(180 \mathrm{mg}, 0.8 \mathrm{mmol}, 10 \%)$ under an atmosphere of $\mathrm{O}_{2}$ at room temperature for $16 \mathrm{~h}$. The reaction was quenched with saturated $\mathrm{NH}_{4} \mathrm{Cl}$ at $0{ }^{\circ} \mathrm{C}$ and extracted with $\mathrm{Et}_{2} \mathrm{O}$. The combined organic phases were dried over $\mathrm{MgSO}_{4}$, filtered and evaporated in vacuo. 23 was obtained as a colorless oil (1.37 g, 69\%), A small amount was further purified by chromatography on preparative $\mathrm{SiO}_{2}$ plates to afford analytically pure material. $[\alpha]_{D}{ }^{20}=-93\left(C=1.5, \mathrm{CHCl}_{3}\right)$ 
${ }^{1} \mathbf{H}$ NMR $\left(400 \mathrm{MHz}, \mathrm{CDCl}_{3}\right): 6.93(\mathrm{br} \mathrm{d}, J=10.2 \mathrm{~Hz}, 1 \mathrm{H}, \mathrm{C}=\mathrm{O}-\mathrm{CH}=\mathrm{CH}), 6.00(\mathrm{br} \mathrm{d}, J=10.2$ $\mathrm{Hz}, 1 \mathrm{H}, \mathrm{C}=\mathrm{O}-\mathrm{CH}=\mathrm{CH}$ ), 3.60 (m, 2H, $\mathrm{CH}_{2}$-OTBS), 2.58 (m, 1H, $\mathrm{CH}-\mathrm{CH}_{2} \mathrm{OTBS}$ ), 2.52 (dt, $J=$ 16.6, $4.9 \mathrm{~Hz}, 1 \mathrm{H}, \mathrm{C}=\mathrm{O}-\mathrm{CH} H$ ), 2.36 (ddd, $J=16.6,12.8,4.9 \mathrm{~Hz}, 1 \mathrm{H}, \mathrm{C}=\mathrm{O}-\mathrm{CH}$ ), 2.07 (dq, $J=$ $12.8,4.9 \mathrm{~Hz}, 1 \mathrm{H}, \mathrm{C}=\mathrm{O}-\mathrm{CH}_{2}-\mathrm{CH}$ ), 1.74 (tdd, $J=12.8,9.9,4.9 \mathrm{~Hz}, 1 \mathrm{H}, \mathrm{C}=\mathrm{O}-\mathrm{CH}_{2}-\mathrm{CH} H$ ), 0.86 (s, 9H, $\left.{ }^{\mathrm{t}} \mathrm{Bu}\right), 0.03$ (s, 6H, $\left.(\mathrm{Me})_{2} \mathrm{Si}\right)$.

${ }^{13} \mathrm{C}$ NMR $\left(100 \mathrm{MHz}, \mathrm{CDCl}_{3}\right): 199.8,151.9,129.9,65.5,39.2,36.7,25.9,25.5,18.3,-5.4$.

Anal. calcd for $\mathrm{C}_{13} \mathrm{H}_{24} \mathrm{O}_{2} \mathrm{Si}$ C: 64.95 ; $\mathrm{H}: 10.06$ Found C: $64.92 ; \mathrm{H}: 10.03$.

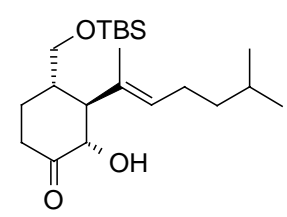

${ }^{t} \mathrm{BuLi}$ (9.1 mL, 1.5M in pentane, $13.65 \mathrm{mmol}, 2.5$ equiv.) was added to a solution of 16 (1.45 $\mathrm{g}, 7.6 \mathrm{mmol}, 1.4$ equiv.) in THF $(40 \mathrm{~mL})$ at $-78^{\circ} \mathrm{C}$. The yellow solution was stirred for $20 \mathrm{~min}$, and a solution of $\mathrm{Li}(2-\mathrm{th}) \mathrm{CuCN}(30.4 \mathrm{~mL}, 0.25 \mathrm{M}$ in THF, $7.6 \mathrm{mmol}, 1.4$ equiv.) was slowly added. The resulting orange-yellow solution was stirred for $20 \mathrm{~min}$ at $-78{ }^{\circ} \mathrm{C}$. A solution of 23 $(1.3 \mathrm{~g}, 5.46 \mathrm{mmol})$ in THF $(10 \mathrm{~mL})$ was transferred to the cuprate solution via cannula, and the resulting mixture was stirred for $30 \mathrm{~min}$ at $-78{ }^{\circ} \mathrm{C}$. TMSCl $(1 \mathrm{~mL}, 8.2 \mathrm{mmol}, 1.5$ equiv.) was then added, and the solution was stirred for $30 \mathrm{~min}$. $\mathrm{Et}_{3} \mathrm{~N}(2 \mathrm{~mL})$ was added and the reaction mixture was transferred via cannula to cool $\left(0^{\circ} \mathrm{C}\right)$ water. The two phase-mixture was separated, the organic phase was extracted with $\mathrm{Et}_{2} \mathrm{O}$, dried over $\mathrm{MgSO}_{4}$ and concentrated in vacuo. The silyl enol ether 24 thus obtained $(2.3 \mathrm{~g})$ was dissolved in $\mathrm{CH}_{2} \mathrm{Cl}_{2}$ $(50 \mathrm{~mL})$, and the solution was cooled to $0{ }^{\circ} \mathrm{C} . \mathrm{KHCO}_{3}(2.5 \mathrm{~g}, 25 \mathrm{mmol}, 5$ equiv.) and $\mathrm{mCPBA}$ ( $70 \%$ purity, $1.3 \mathrm{~g}, 5.5 \mathrm{mmol}, 1$ equiv.) were successively added and the suspension was vigorously stirred for $1 \mathrm{~h}$. The solid was filtered-off, the solution was quenched with $10 \%$ aqueous $\mathrm{Na}_{2} \mathrm{~S}_{2} \mathrm{O}_{3}$ and extracted with $\mathrm{CH}_{2} \mathrm{Cl}_{2}$. The combined organic phases were dried over $\mathrm{MgSO}_{4}$ and concentrated in vacuo. The residue was dissolved in a mixture of $\mathrm{MeOH}$ and THF $(10 / 1,55 \mathrm{~mL})$, the solution was cooled at $0{ }^{\circ} \mathrm{C}$ and TFA (38 $\mu \mathrm{L}, 0.5 \mathrm{mmol}, 0.1$ equiv.) was added. The mixture was stirred for $30 \mathrm{~min}$ and the reaction was stopped with saturated $\mathrm{NaHCO}_{3}$. After extraction with $\mathrm{Et}_{2} \mathrm{O}$, the combined organic phases were dried over $\mathrm{MgSO}_{4}$ and concentrated in vacuo. Chromatography $\left(\mathrm{SiO}_{2}, 230-400\right.$ mesh, cyclohexane / AcOEt 9/1) afforded 25 as a colorless oil (1.04 g, 52\%). e.e. $=85 \%$ (Chiral HPLC, Chiralpack AD).

${ }^{1} \mathbf{H}$ NMR $\left(400 \mathrm{MHz}, \mathrm{CDCl}_{3}\right): 5.25$ (t, $\left.J=6.6 \mathrm{~Hz}, \mathrm{C}=\mathrm{CH}\right), 4.12(\mathrm{~d}, J=11.2 \mathrm{~Hz}, 1 \mathrm{H}, \mathrm{CHOH})$, 3.54 (dd, $J=10.1,3.3 \mathrm{~Hz}, 1 \mathrm{H}, \mathrm{CHH}-\mathrm{OTBS}$ ), 3.44 (br s, 1H, OH), 3.28 (dd, $J=10.1,6.8 \mathrm{~Hz}$, 1H, CHH-OTBS), 2.59 (ddd, $J=14.0,4.5,2.5 \mathrm{~Hz}, 1 \mathrm{H}, \mathrm{CH}-\mathrm{C}=\mathrm{O}$ ), 2.43 (td, $J=14.0,6.3 \mathrm{~Hz}$, $1 \mathrm{H}, \mathrm{CH}-\mathrm{C}=\mathrm{O}), 2.25\left(\mathrm{~m}, 1 \mathrm{H}, \mathrm{CH}-\mathrm{CH}_{2}-\mathrm{C}=\mathrm{O}\right), 2.12-2.01\left(\mathrm{~m}, 3 \mathrm{H}, \mathrm{CH}-\mathrm{CH}-\mathrm{OH} \& \mathrm{C}=\mathrm{CH}-\mathrm{CH}_{2}\right)$, 
$1.95\left(\mathrm{~m}, 1 \mathrm{H}, \mathrm{CH}-\mathrm{CH}_{2} \mathrm{OTBS}\right), 1.66$ (s, 3H, Me), 1.59-1.47 (m, 2H, $\left.\mathrm{CH}-\mathrm{CH}_{2}-\mathrm{C}=\mathrm{O} \& \mathrm{CH}(\mathrm{Me})_{2}\right)$, $1.23\left(\mathrm{q}, J=7.4 \mathrm{~Hz}, 2 \mathrm{H}, \mathrm{CH}_{2}-\mathrm{CH}(\mathrm{Me})_{2}\right), 0.88\left(\mathrm{~d}, J=7.4 \mathrm{~Hz}, 6 \mathrm{H},(\mathrm{Me})_{2}-\mathrm{CH}\right), 0.87\left(\mathrm{~s}, 9 \mathrm{H},{ }^{t} \mathrm{Bu}\right)$, $0.00\left(\mathrm{~s}, 6 \mathrm{H},(\mathrm{Me})_{2} \mathrm{Si}\right)$.

${ }^{13} \mathrm{C}$ NMR $\left(100 \mathrm{MHz}, \mathrm{CDCl}_{3}\right): 210.9,131.1,130.2,75.5,64.5,58.7,39.4,38.8,38.1,29.3$, $27.5,25.9,25.6,22.6,22.3,18.2,11.7,-5.5,-5.6$.

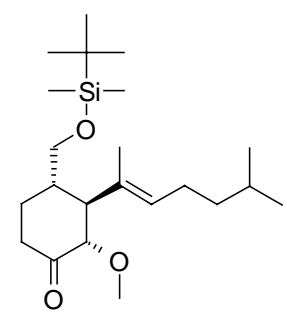

Mel (3 mL) was added to a mixture of silver oxide $(3.15 \mathrm{~g}, 13.5 \mathrm{mmol}, 5$ equiv.), $4 \AA$ molecular sieve $(800 \mathrm{mg})$ and $25(1 \mathrm{~g}, 2.7 \mathrm{mmol})$ in $\mathrm{Et}_{2} \mathrm{O}(10 \mathrm{~mL})$. The suspension was stirred for $3 \mathrm{~h}$ at $40{ }^{\circ} \mathrm{C}$, and the solid was filtered over celite. The solvents were removed in vacuo and the residue was chromatographed $\left(\mathrm{SiO}_{2}\right.$, cyclohexane / AcOEt 9/1) to afford 26 as a colorless oil $(1.0 \mathrm{~g}, 96 \%) .[\alpha]_{\mathrm{D}}^{20}=-4.0\left(\mathrm{C}=1.7, \mathrm{CHCl}_{3}\right)$

${ }^{1} \mathrm{H}$ NMR $\left(400 \mathrm{MHz}, \mathrm{CDCl}_{3}\right): 5.21(\mathrm{t}, J=6.8 \mathrm{~Hz}, \mathrm{C}=\mathrm{CH}), 4.12(\mathrm{~d}, J=11.4 \mathrm{~Hz}, \mathrm{CH}-\mathrm{OMe}), 3.54$ (dd, $J=9.8,3.1 \mathrm{~Hz}, 1 \mathrm{H}, \mathrm{CH}$-OTBS), 3.39 (s, 3H, OMe), 3.29 (dd, $J=9.8,6.8 \mathrm{~Hz}, 1 \mathrm{H}, \mathrm{CH}$ OTBS), 2.45 (ddd, $J=13.4,4.8,3.0 \mathrm{~Hz}, 1 \mathrm{H}, \mathrm{CH} H-\mathrm{C}=\mathrm{O}$ ), 2.42-2.32 (m, 1H, CHH-C=O), 2.25 (t, $J=11.4 \mathrm{~Hz}, 1 \mathrm{H}, \mathrm{CH}-\mathrm{C}(\mathrm{Me})=\mathrm{C}), 2.18\left(\mathrm{~m}, 1 \mathrm{H}, \mathrm{CH}-\mathrm{CH}_{2}-\mathrm{C}=\mathrm{O}\right), 2.04\left(\mathrm{~m}, 2 \mathrm{H}, \mathrm{C}=\mathrm{CH}-\mathrm{CH}{ }_{2}\right)$, $1.92\left(\mathrm{~m}, 1 \mathrm{H}, \mathrm{CH}-\mathrm{CH}_{2}-\mathrm{OTBS}\right), 1.61(\mathrm{~s}, 3 \mathrm{H}, \mathrm{Me}), 1.60-1.45\left(\mathrm{~m}, 3 \mathrm{H}, \mathrm{CH}_{2}-\mathrm{CH}(\mathrm{Me})_{2} \& \mathrm{CHH}_{-} \mathrm{CH}_{2-}\right.$ $\mathrm{C}=\mathrm{O}), 1.23\left(\mathrm{~m}, 2 \mathrm{H}, \mathrm{CH}_{2}-\mathrm{CH}(\mathrm{Me})_{2}\right), 0.88\left(\mathrm{~d}, J=6.8 \mathrm{~Hz}, 6 \mathrm{H},(\mathrm{Me})_{2}-\mathrm{CH}\right), 0.86\left(\mathrm{~s}, 9 \mathrm{H},{ }^{\mathrm{t}} \mathrm{Bu}\right), 0.00$ (s, 6H, $\left.(\mathrm{Me})_{2} \mathrm{Si}\right)$.

${ }^{13} \mathrm{C}$ NMR $\left(100 \mathrm{MHz}, \mathrm{CDCl}_{3}\right): 209.6,131.2,129.5,84.9,64.5,58.9,56.5,40.4,39.7,38.7$, $29.4,27.4,25.9,25.6,22.6,22.5,18.3,12.0,-5.4,-5.5$.

(27)

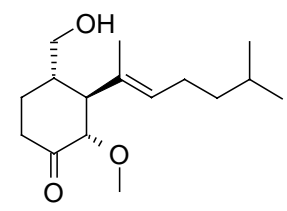

TBAF (2.2 mL, $2.2 \mathrm{mmol}, 1.1$ equiv.) was added to a solution of 26 (765 mg, $2.0 \mathrm{mmol}$ ) in THF $(50 \mathrm{~mL})$. The mixture was stirred for $4 \mathrm{~h}$ at room temperature and the reaction was stopped with saturated $\mathrm{NH}_{4} \mathrm{Cl}$ and extracted with AcOEt. The combined organic phases were 
dried over $\mathrm{MgSO}_{4}$ and concentrated in vacuo. Chromatography $\left(\mathrm{SiO}_{2}\right.$, cyclohexane / $\mathrm{AcOEt}$ 9/1 $\rightarrow 8 / 2$ ) afforded 27 as a colorless oil (450 mg, 84\%). $[\alpha]_{\mathrm{D}}{ }^{20}=-14.9\left(C=1.75, \mathrm{CHCl}_{3}\right)$.

${ }^{1} \mathrm{H}$ NMR $\left(400 \mathrm{MHz}, \mathrm{CDCl}_{3}\right): 5.28(\mathrm{t}, J=7.0 \mathrm{~Hz}, \mathrm{C}=\mathrm{CH}), 3.76(\mathrm{~d}, J=11.5 \mathrm{~Hz}, 1 \mathrm{H}, \mathrm{CHOMe})$, 3.59 (dd, $J=11.2,4.4 \mathrm{~Hz}, 1 \mathrm{H}, \mathrm{CHH}-\mathrm{OH}$ ), 3.42 (dd, $J=11.2,6.0 \mathrm{~Hz}, 1 \mathrm{H}, \mathrm{CH}-\mathrm{OH}$ ), 3.40 (s, $3 \mathrm{H}, \mathrm{OMe}$ ), 2.48 (ddd, $J=13.7,5.0,3.0 \mathrm{~Hz}, 1 \mathrm{H}, \mathrm{CH} H-\mathrm{C}=\mathrm{O}$ ), 2.41 (tdd, $J=13.7,6.0,1.0 \mathrm{~Hz}$, $1 \mathrm{H}, \mathrm{CHH}-\mathrm{C}=\mathrm{O}$ ), 2.23 (t, $J=11.5 \mathrm{~Hz}, 1 \mathrm{H}, \mathrm{CH}-\mathrm{C}(\mathrm{Me})=\mathrm{C}), 2.14\left(\mathrm{~m}, 1 \mathrm{H}, \mathrm{CH}-\mathrm{CH}_{2}-\mathrm{C}=\mathrm{O}\right), 2.06-$ $2.02\left(\mathrm{~m}, 3 \mathrm{H}, \mathrm{C}=\mathrm{CH}-\mathrm{CH}_{2} \& \mathrm{CH} H-\mathrm{CH}_{2}-\mathrm{C}=\mathrm{O}\right), 1.65$ (s, 3H, Me), $1.55\left(\mathrm{~m}, 3 \mathrm{H}, \mathrm{CH}_{2}-\mathrm{CH}(\mathrm{Me})_{2}\right.$ \& $\left.\mathrm{OH} \& \mathrm{CH}-\mathrm{CH}_{2} \mathrm{OH}\right), 1.23\left(\mathrm{~m}, 2 \mathrm{H}, \mathrm{CH}_{2}-\mathrm{CH}(\mathrm{Me})_{2}\right), 0.87$ (d, J = 7.0, 6H, (Me) $\left.)_{2}-\mathrm{CH}\right)$.

${ }^{13} \mathrm{C}$ NMR $\left(100 \mathrm{MHz}, \mathrm{CDCl}_{3}\right): 209.0,132.2,129.9,84.6,65.2,58.9,57.5,40.6,39.6,38.6$, 29.2, 27.6, 25.7, 22.5, 11.9 .

Anal. calcd for $\mathrm{C}_{16} \mathrm{H}_{28} \mathrm{O}_{3}$ : C, 71.60; $\mathrm{H}, 10.52$; Found: $\mathrm{C}, 71.18 ; \mathrm{H}, 10.67$.

HRMS (FAB) $m / z$ found 268.2043, calcd for $\mathrm{C}_{16} \mathrm{H}_{28} \mathrm{O}_{3} \mathrm{~m} / \mathrm{z} 268.2038$.

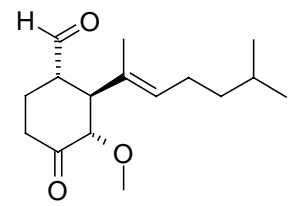

Dess Martin periodinane ( $4.2 \mathrm{~mL}, 15 \%$ solution in $\mathrm{CH}_{2} \mathrm{Cl}_{2}, 1.2$ equiv.) was added to a solution of 27 (430 mg, $1.67 \mathrm{mmol})$ in $\mathrm{CH}_{2} \mathrm{Cl}_{2}(10 \mathrm{~mL})$ in the presence of water $(20 \mu \mathrm{L})$. The mixture was stirred for $2 \mathrm{~h}$ at room temperature, and the reaction was stopped with saturated $\mathrm{NaHCO}_{3}$ and $\mathrm{Na}_{2} \mathrm{~S}_{2} \mathrm{O}_{3}(1 / 1)$. This mixture was vigorously stirred for $1 \mathrm{~h}$, the two phasemixture was separated and the organic layer was extracted with $\mathrm{CH}_{2} \mathrm{Cl}_{2}$. The combined organic phases were dried over $\mathrm{MgSO}_{4}$ and concentrated in vacuo. Chromatography $\left(\mathrm{SiO}_{2}\right.$, cyclohexane / AcOEt $9 / 1 \rightarrow 8 / 2$ ) afforded 28 as a colorless oil $(355 \mathrm{mg}, 83 \%)$. $[\alpha]_{\mathrm{D}}{ }^{20}=+3.3$ $\left(C=1.0, \mathrm{CHCl}_{3}\right)$.

${ }^{1}$ H NMR $\left(400 \mathrm{MHz}, \mathrm{CDCl}_{3}\right): 9.47(\mathrm{~d}, J=3.0 \mathrm{~Hz}, 1 \mathrm{H}, \mathrm{CHO}), 5.31(\mathrm{t}, J=7.0 \mathrm{~Hz}, 1 \mathrm{H}, \mathrm{C}=\mathrm{CH})$, 3.77 (d, $J=9.6 \mathrm{~Hz}, 1 \mathrm{H}, \mathrm{CH}-\mathrm{OMe}$ ), 3.40 (s, 3H, OMe), 2.65 (tt, $J=10.8,3.0 \mathrm{~Hz}, 1 \mathrm{H}, \mathrm{CH}-$ $\mathrm{CHO}$ ), 2.70 (t, $J=10.8 \mathrm{~Hz}, 1 \mathrm{H}, \mathrm{CH}-\mathrm{C}(\mathrm{Me})=\mathrm{CH}$ ), 2.57 (dt, $J=13.3,4.3 \mathrm{~Hz}, 1 \mathrm{H}, \mathrm{CH}-\mathrm{C}=\mathrm{O}$ ), $2.41(\mathrm{td}, J=13.3,5.8,1 \mathrm{H}, \mathrm{CH} H-\mathrm{C}=\mathrm{O}), 2.09\left(\mathrm{~m}, 1 \mathrm{H}, \mathrm{CHH}-\mathrm{CH}_{2}-\mathrm{C}=\mathrm{O}\right), 2.02(\mathrm{q}, J=7.0,2 \mathrm{H}$, $\left.\mathrm{C}(\mathrm{Me})=\mathrm{CH}-\mathrm{CH}_{2}\right), 1.81\left(\mathrm{~m}, .1 \mathrm{H}, \mathrm{CHH}-\mathrm{CH}_{2}-\mathrm{C}=\mathrm{O}\right), 1.67(\mathrm{~s}, 3 \mathrm{H}, \mathrm{Me}), 1.51\left(\mathrm{~m}, 1 \mathrm{H}, \mathrm{CH}_{2}-\right.$ $\left.\mathrm{CH}(\mathrm{Me})_{2}\right), 1.20\left(\mathrm{~m}, 2 \mathrm{H}, \mathrm{CH}_{2}-\mathrm{CH}(\mathrm{Me})_{2}\right), 0.86\left(\mathrm{~d}, J=6.7 \mathrm{~Hz}, 6 \mathrm{H},(\mathrm{Me})_{2}-\mathrm{CH}\right)$.

${ }^{13} \mathrm{C}$ NMR $\left(100 \mathrm{MHz}, \mathrm{CDCl}_{3}\right): 207.6,201.5,130.9,130.5,84.4,58.9,54.9,50.4,38.6,38.4$, 27.5, 25.7, 25.4, 22.4, 12.9.

HRMS (FAB) $m / z$ found 266.1885, calcd for $\mathrm{C}_{16} \mathrm{H}_{26} \mathrm{O}_{3} \mathrm{~m} / \mathrm{z}: 266.1882$. 


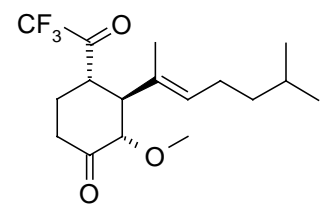

$\mathrm{CF}_{3} \mathrm{SiMe}_{3}(30 \mu \mathrm{L}, 0.197 \mathrm{mmol}, 1.05$ equiv.) and TBAF (10 $\mu \mathrm{L}, 1 \mathrm{M}$ in THF, 0.05 equiv.) were added to a solution of $28(50 \mathrm{mg}, 188 \mu \mathrm{mol})$ in THF $(1 \mathrm{~mL})$ at $0{ }^{\circ} \mathrm{C}$ and the mixture was stirred for $1 \mathrm{~h}$ at this temperature. The reaction was stopped with saturated $\mathrm{NH}_{4} \mathrm{Cl}$ and extracted with ethyl acetate. The combined organic phases were dried over $\mathrm{MgSO}_{4}$, filtered and concentrated in vacuo. The residue was dissolved in THF $(1 \mathrm{~mL})$ and treated with TBAF (200 $\mu \mathrm{L}, 1 \mathrm{M}$ in THF, 1 equiv.). The mixture was stirred for $30 \mathrm{~min}$ and the reaction was stopped with saturated $\mathrm{NH}_{4} \mathrm{Cl}$. After extraction with ethyl acetate, the combined organic phases were dried over $\mathrm{MgSO}_{4}$, filtered and concentrated in vacuo. The residue was dissolved in $\mathrm{CH}_{2} \mathrm{Cl}_{2}(1 \mathrm{~mL})$ and treated with Dess Martin periodinane $\left(15 \%\right.$ in $\mathrm{CH}_{2} \mathrm{Cl}_{2}, 1.6 \mathrm{~mL}$, $0.77 \mathrm{mmol}, 4$ equiv.) at $0{ }^{\circ} \mathrm{C}$. The mixture was stirred for $16 \mathrm{~h}$ at this temperature, and the reaction was stopped with saturated $\mathrm{NaHCO}_{3}$ and $10 \% \mathrm{Na}_{2} \mathrm{~S}_{2} \mathrm{O}_{3}$ at $0{ }^{\circ} \mathrm{C}$. The mixture was vigorously stirred for $1 \mathrm{~h}$ at this temperature, and then extracted with $\mathrm{CH}_{2} \mathrm{Cl}_{2}$. The combined organic phases were dried over $\mathrm{MgSO}_{4}$, filtered and concentrated in vacuo. Chromatography on preparative $\mathrm{TLC}\left(\mathrm{SiO}_{2}\right.$ cyclohexane / $\mathrm{Et}_{2} \mathrm{O}$ 9/1) afforded pure 29 as a colorless oil (25 mg, $40 \%) .[\alpha]_{D}^{20}=-8\left(C=0.5, \mathrm{CHCl}_{3}\right)$.

${ }^{1} \mathrm{H}$ NMR $\left(400 \mathrm{MHz}, \mathrm{CDCl}_{3}\right): 5.22(\mathrm{t}, J=7.0 \mathrm{~Hz}, 1 \mathrm{H}, \mathrm{C}=\mathrm{CH}), 3.80(\mathrm{~d}, J=11.6 \mathrm{~Hz}, 1 \mathrm{H}, \mathrm{CH}-$ OMe), 3.46 (td, $\left.J=11.6,3.5 \mathrm{~Hz}, 1 \mathrm{H}, \mathrm{CH}-\mathrm{CO}\left(\mathrm{CF}_{3}\right)\right), 3.42$ (s, 3H, OMe), 2.82 (t, $J=11.6 \mathrm{~Hz}$, $1 \mathrm{H}, \mathrm{CH}-\mathrm{C}(\mathrm{Me})=\mathrm{CH}$ ), 2.57 (ddd, $J=13.5,4.5,3.0 \mathrm{~Hz}, 1 \mathrm{H}, \mathrm{CH}-\mathrm{CO}$ ), 2.47 (td, $J=13.5,5.8$ $\mathrm{Hz}, 1 \mathrm{H}, \mathrm{CH}-\mathrm{CO}$ ), $2.21\left(\mathrm{~m}, 1 \mathrm{H}, \mathrm{C}=\mathrm{O}-\mathrm{CH}_{2}-\mathrm{CH} H\right), 1.97$ (q, J = 7.6 Hz, 2H, CH$H_{2} \mathrm{CH}=\mathrm{C}$ ), 1.81 (tdd, $\left.J=13.5,11.6,4.5 \mathrm{~Hz}, 1 \mathrm{H}, \mathrm{C}=\mathrm{O}-\mathrm{CH}_{2}-\mathrm{CH}\right), 1.64(\mathrm{~s}, 3 \mathrm{H}, \mathrm{Me}), 1.47\left(\mathrm{~m}, 1 \mathrm{H}, \mathrm{CH}(\mathrm{Me})_{2}\right)$, $1.15\left(\mathrm{~m}, 2 \mathrm{H}, \mathrm{CH}_{2}-\mathrm{CH}(\mathrm{Me})_{2}\right), 0.85 \& 0.84\left(2 \mathrm{~d}, J=6.5 \mathrm{~Hz}, 6 \mathrm{H},(\mathrm{Me})_{2}\right)$.

${ }^{13} \mathrm{C}$ NMR $\left(100 \mathrm{MHz}, \mathrm{CDCl}_{3}\right): 206.4,191.3\left(\mathrm{q},{ }^{2} \mathrm{~J}_{\mathrm{C}-\mathrm{F}}=35.3 \mathrm{~Hz}\right), 131.6,130.6,115.4\left(\mathrm{q},{ }^{1} \mathrm{~J}_{\mathrm{C}-\mathrm{F}}=\right.$ $29.03 \mathrm{~Hz}), 84.5,59.1,55.3,46.5,39.1,38.1,28.8,27.4,25.6,22.4,22.3,12.9 .{ }^{19} \mathrm{~F}$ NMR (376 $\left.\mathrm{MHz}, \mathrm{CDCl}_{3}\right):-74.9$ (s).

HRMS (FAB) $m / z$ found 334.1755, calcd for $\mathrm{C}_{17} \mathrm{H}_{25} \mathrm{O}_{3} \mathrm{~F}_{3} \mathrm{~m} / \mathrm{z}: 334.1756$.

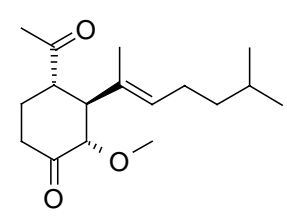


MeLi (1.4M in $\mathrm{Et}_{2} \mathrm{O}, 64 \mu \mathrm{L}, 0.090 \mathrm{mmol}, 1.2$ equiv.) was added to a solution of 28 (20 mg, $0.075 \mathrm{mmol})$ in THF $(2 \mathrm{~mL})$ at $-78^{\circ} \mathrm{C}$. This solution was stirred for $30 \mathrm{~min}$, then the reaction was stopped with saturated $\mathrm{NH}_{4} \mathrm{Cl}$ and extracted with AcOEt. The combined organic phases were dried over $\mathrm{MgSO}_{4}$, filtered and concentrated in vacuo. The residue was dissolved in $\mathrm{CH}_{2} \mathrm{Cl}_{2}(0.5 \mathrm{~mL})$ and treated with Dess Martin periodinane $\left(15 \%\right.$ in $\mathrm{CH}_{2} \mathrm{Cl}_{2}, 280 \mu \mathrm{L}, 0.11$ mmol, 1.4 equiv.). The mixture was stirred for $30 \mathrm{~min}$, and the reaction was stopped with saturated $\mathrm{NaHCO}_{3}(1 \mathrm{~mL})$ and saturated $\mathrm{Na}_{2} \mathrm{~S}_{2} \mathrm{O}_{3}(1 \mathrm{~mL})$ at $0{ }^{\circ} \mathrm{C}$. After being vigorously stirred for 30 min at this temperature, the mixture was extracted with $\mathrm{CH}_{2} \mathrm{Cl}_{2}$. The combined organic phases were dried over $\mathrm{MgSO}_{4}$, filtered and concentrated in vacuo. Chromatography on preparative $\mathrm{SiO}_{2}$ plates (cyclohexane / AcOEt 9/1) afforded pure 31 as a colorless oil (16 $\mathrm{mg}, 76 \%) .[\alpha]_{\mathrm{D}}{ }^{20}=-9.4\left(\mathrm{C}=0.8, \mathrm{CHCl}_{3}\right)$

${ }^{1} \mathrm{H}$ NMR $\left(400 \mathrm{MHz}, \mathrm{CDCl}_{3}\right) 5.24(\mathrm{t}, J=7.0 \mathrm{~Hz}, 1 \mathrm{H},(\mathrm{Me}) \mathrm{C}=\mathrm{CH}), 3.74(\mathrm{~d}, J=11.6 \mathrm{~Hz}, 1 \mathrm{H}$, $\mathrm{CH}$-OMe), 3.40 (s, 3H, OMe), 3.00 (td, $J=11.6,3.6 \mathrm{~Hz}, 1 \mathrm{H}, \mathrm{CH}-\mathrm{C}=\mathrm{O}(\mathrm{Me})$ ), 2.61 (t, $J=11.6$ $\mathrm{Hz}, 1 \mathrm{H}, \mathrm{CH}-\mathrm{C}(\mathrm{Me})=\mathrm{CH}$ ), $2.53\left(\mathrm{ddd}, J=13.6,4.5,3.0 \mathrm{~Hz}, 1 \mathrm{H}, \mathrm{CH}_{\text {eq }} \mathrm{C}=\mathrm{O}\right), 2.41$ (td, $J=13.6$, $5.8 \mathrm{~Hz}, 1 \mathrm{H}, \mathrm{CH} H_{a x}-\mathrm{C}=\mathrm{O}$ ), 2.07 (s, 3H, Me-C=O), 2.05 (m, 1H, CHH-CH${ }_{2}-\mathrm{C}=\mathrm{O}$ ), 2.00 (q, $J=$ $\left.7.0 \mathrm{~Hz}, \mathrm{C}=\mathrm{CH}-\mathrm{CH}_{2}\right), 1.79\left(\mathrm{~m}, 1 \mathrm{H}, \mathrm{CH}-\mathrm{CH}_{2}-\mathrm{C}=\mathrm{O}\right), 1.66(\mathrm{~s}, 3 \mathrm{H}, \mathrm{Me}-\mathrm{C}=\mathrm{CH}), 1.51(\mathrm{~m}, 1 \mathrm{H}$, $\left.\mathrm{CH}(\mathrm{Me})_{2}\right), 1.18\left(\mathrm{~m}, 2 \mathrm{H}, \mathrm{CH}_{2}-\mathrm{CH}(\mathrm{Me})_{2}\right), 0.86 \& 0.85\left(2 \mathrm{~d}, J=6.7 \mathrm{~Hz}, 6 \mathrm{H}, \mathrm{CH}(\mathrm{Me})_{2}\right)$.

${ }^{13} \mathrm{C}$ NMR $\left(100 \mathrm{MHz}, \mathrm{CDCl}_{3}\right): 208.6,207.6,131.3,130.4,84.9,59.0,56.4,53.4,39.4,38.5$, 29.0, 28.2, 27.5, 25.7, 22.5, 12.8.

HRMS (FAB) $m / z$ found 248.1778 , calcd for $\mathrm{C}_{16} \mathrm{H}_{24} \mathrm{O}_{2}\left(\mathrm{M}-\mathrm{CH}_{3} \mathrm{OH}\right) \mathrm{m} / \mathrm{z}: 248.1777$.

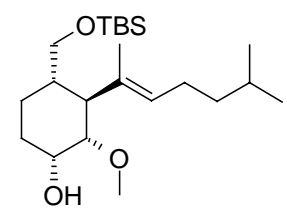

L-Selectride (1M in THF, $0.35 \mathrm{~mL}, 1.5$ equiv.) was added to a solution of 26 (85 $\mathrm{mg}, 0.222$ $\mathrm{mmol})$ in THF $(1.5 \mathrm{~mL})$ at $-78^{\circ} \mathrm{C}$. The reaction was stirred for $1 \mathrm{~h}$ at this temperature, then stopped with saturated $\mathrm{NH}_{4} \mathrm{Cl}$ and extracted with AcOEt. The combined organic phases were dried over $\mathrm{MgSO}_{4}$, filtered and concentrated in vacuo. Chromatography on preparative $\mathrm{SiO}_{2}$ plates (cyclohexane / $\left.\mathrm{Et}_{2} \mathrm{O} 85 / 15\right)$ afforded pure 32 as a colorless oil $(60 \mathrm{mg}, 70 \%) .[\alpha]_{\mathrm{D}}{ }^{20}=$ $+15\left(\mathrm{C}=0.8, \mathrm{CHCl}_{3}\right)$.

${ }^{1} \mathrm{H}$ NMR $\left(400 \mathrm{MHz}, \mathrm{CDCl}_{3}\right): 5.19(\mathrm{t}, J=7.5 \mathrm{~Hz}, 1 \mathrm{H}, \mathrm{C}=\mathrm{CH}), 4.20$ (br s, $\left.1 \mathrm{H}, \mathrm{CH}-\mathrm{OH}\right), 3.49$ (dd, $J=10.0,2.5 \mathrm{~Hz}, 1 \mathrm{H}, \mathrm{CHH}-\mathrm{OTBS}$ ), 3.34 (s, 3H, OMe), 3.19 (dd, $J=10.0,7.4 \mathrm{~Hz}, 1 \mathrm{H}$, CHH-OTBS), 3.08 (dd, $J=10.7,2.7 \mathrm{~Hz}, 1 \mathrm{H}, \mathrm{CH}$-OMe), 2.16 (t, $J=10.7 \mathrm{~Hz}, 1 \mathrm{H}, \mathrm{CH}$ $\mathrm{C}(\mathrm{Me})=\mathrm{CH}), 2.15(\mathrm{br} \mathrm{s}, 1 \mathrm{H}, \mathrm{OH}), 2.10-2.00\left(\mathrm{~m}, 3 \mathrm{H}, \mathrm{C}=\mathrm{CH}-\mathrm{CH}_{2} \& \mathrm{CH}-\mathrm{CHOH}\right), 1.68(\mathrm{~m}, 1 \mathrm{H}$, $\mathrm{CH}-\mathrm{CHOH}), 1.56\left(\mathrm{~s}, 3 \mathrm{H}, \mathrm{CH}_{3} \mathrm{C}=\mathrm{CH}\right), 1.55\left(\mathrm{~m}, 1 \mathrm{H}, \mathrm{CH}(\mathrm{Me})_{2}\right), 1.45-1.35(\mathrm{~m}, 3 \mathrm{H}, \mathrm{CH}-$ 
$\left.\mathrm{CH}_{2} \mathrm{OTBS} \& \mathrm{CH}_{2}-\mathrm{CH}\left(\mathrm{CH}_{2} \mathrm{OTBS}\right)\right), 1.24$ (q, $\left.\mathrm{J}=7.0 \mathrm{~Hz}, 2 \mathrm{H}, \mathrm{CH}_{2}-\mathrm{CH}(\mathrm{Me})_{2}\right), 0.88 \& 0.87$ (2d, J $\left.=7.0 \mathrm{~Hz}, 6 \mathrm{H}, \mathrm{CH}(\mathrm{Me})_{2}\right), 0.87\left(\mathrm{~s}, 9 \mathrm{H},{ }^{\mathrm{t}} \mathrm{Bu}\right), 0.00\left(\mathrm{~s}, 6 \mathrm{H},(\mathrm{Me})_{2} \mathrm{Si}\right)$.

${ }^{13} \mathrm{C}$ NMR $\left(100 \mathrm{MHz}, \mathrm{CDCl}_{3}\right): 132.6,128.3,82.4,65.8,64.9,57.1,48.7,40.7,38.9,29.1$, $27.5,26.0,25.6,22.6,22.4,18.4,-5.3,-5.4$.

Anal. calcd for $\mathrm{C}_{22} \mathrm{H}_{44} \mathrm{O}_{3} \mathrm{Si}$ C: $68.69 ; \mathrm{H}: 11.53$ Found C: 68.83; $\mathrm{H}: 11.74$.

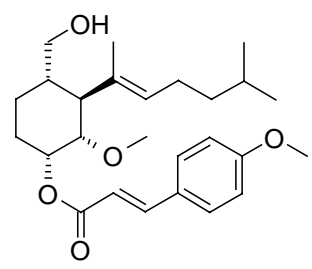

p-Methoxycinnamic acid (104 mg, $0.58 \mathrm{mmol}, 5$ equiv.) followed by DMAP (71 $\mathrm{mg}, 0.58$ mmol, 5 equiv.) and DCC (120 mg, $0.58 \mathrm{mmol}, 5$ equiv.) were added to a solution of 32 (45 $\mathrm{mg}, 0.117 \mathrm{mmol}, 1.0$ equiv.) in dichloromethane $(3 \mathrm{~mL})$. The mixture was stirred for $48 \mathrm{~h}$ at room temperature, the solvent was removed in vacuo and the residue filtered through a short pad of silica gel (cyclohexane / AcOEt 9/1). The impure oil obtained was dissolved in THF (2 $\mathrm{mL})$ and TBAF ( $0.15 \mathrm{~mL}, 1.3$ equiv.) was added. The mixture was stirred for $16 \mathrm{~h}$ at room temperature and, then, the reaction was stopped with saturated $\mathrm{NH}_{4} \mathrm{Cl}$ and extracted with AcOEt. The combined organic phases were dried over $\mathrm{MgSO}_{4}$, filtered and concentrated in vacuo. Chromatography on preparative $\mathrm{SiO}_{2}$ plates ( $n$-hexane / AcOEt 8/2) afforded pure 36 as a colorless oil $(40 \mathrm{mg}, 80 \%) \cdot[\alpha]_{\mathrm{D}}^{20}=-100\left(C=1.0, \mathrm{CHCl}_{3}\right)$.

${ }^{1} \mathrm{H}$ NMR $\left(400 \mathrm{MHz}, \mathrm{CDCl}_{3}\right): 7.63(\mathrm{~d}, J=16.0 \mathrm{~Hz}, 1 \mathrm{H}, \mathrm{CH}=\mathrm{CH}-\mathrm{COO}), 7.48(\mathrm{~d}, J=8.8 \mathrm{~Hz}, 1 \mathrm{H}$, ArH), 6.89 (d, $J=8.8 \mathrm{~Hz}, 1 \mathrm{H}, \mathrm{ArH}) 6.38(\mathrm{~d}, J=16.0 \mathrm{~Hz}, 1 \mathrm{H}, \mathrm{CH}=\mathrm{CH}-\mathrm{COO}), 5.59(\mathrm{br} \mathrm{s}, 1 \mathrm{H}$, $\mathrm{CH}-\mathrm{O}-\mathrm{C}=\mathrm{O}$ ), $5.36(\mathrm{t}, \mathrm{J}=6.6 \mathrm{~Hz}, 1 \mathrm{H},(\mathrm{Me}) \mathrm{C}=\mathrm{CH}$ ), $3.84(\mathrm{~s}, 3 \mathrm{H}, \mathrm{OMe}), 3.58(\mathrm{dd}, J=11.2,4.8$ $\mathrm{Hz}, 1 \mathrm{H}, \mathrm{CH} H-\mathrm{OH}$ ), 3.43 (dd, $J=11.2,5.6,1 \mathrm{H}, \mathrm{CH}-\mathrm{OH}$ ), 3.32 (s, 3H, OMe), 3.20 (dd, $J=$ 11.5, 2.8, 1H, CH-OMe), 2.37 (t, $J=11.5 \mathrm{~Hz}, 1 \mathrm{H}, \mathrm{CH}-\mathrm{C}(\mathrm{Me})=\mathrm{C}), 2.15-1.95(\mathrm{~m}, 3 \mathrm{H}), 1.75-$ $1.35(\mathrm{~m}, 6 \mathrm{H}), 1.62(\mathrm{~s}, 3 \mathrm{H}, \mathrm{Me}-\mathrm{C}=\mathrm{CH}), 1.26-1.22\left(\mathrm{~m}, 2 \mathrm{H}, \mathrm{CH}_{2}-\mathrm{CH}(\mathrm{Me})_{2}\right), 0.88 \& 0.87(2 \mathrm{~d}, J=$ $\left.6.6 \mathrm{~Hz}, 6 \mathrm{H}, \mathrm{CH}(\mathrm{Me})_{2}\right)$.

${ }^{13} \mathrm{C}$ NMR $\left(100 \mathrm{MHz}, \mathrm{CDCl}_{3}\right): 166.9,161.3,144.3,133.8,129.7,128.9,127.3,116.1,114.2$, $80.5,66.7,66.4,57.1,55.3,50.9,40.8,38.8,33.9,28.1,27.7,25.6,23.1,22.5,22.4$.

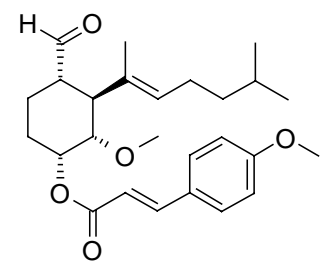


Dess Martin periodinane ( $15 \%$ solution in $\mathrm{CH}_{2} \mathrm{Cl}_{2}, 220 \mu \mathrm{L}, 0.105 \mathrm{mmol}, 1.5$ equiv.) was added to a solution of 33 (30 mg, $0.07 \mathrm{mmol})$ in $\mathrm{CH}_{2} \mathrm{Cl}_{2}(1 \mathrm{~mL})$. The mixture was stirred for 16 $\mathrm{h}$ at room temperature and then stopped with saturated $\mathrm{NaHCO}_{3}(1 \mathrm{~mL})$ and saturated $\mathrm{Na}_{2} \mathrm{~S}_{2} \mathrm{O}_{3}(1 \mathrm{~mL})$. After being vigorously stirred for $30 \mathrm{~min}$ at this temperature, the mixture was extracted with $\mathrm{CH}_{2} \mathrm{Cl}_{2}$. The combined organic phases were dried over $\mathrm{MgSO}_{4}$, filtered and concentrated in vacuo. Chromatography on preparative $\operatorname{TLC}\left(\mathrm{SiO}_{2} n\right.$-hexane / AcOEt 9/1) afforded aldehyde 34 as a colorless oil (26 mg, 87\%). $[\alpha]_{D}{ }^{20}=-50\left(C=0.65, \mathrm{CHCl}_{3}\right)$.

${ }^{1} \mathrm{H}$ NMR (400 MHz, $\left.\mathrm{CDCl}_{3}\right): 9.49(\mathrm{~d}, J=3.7 \mathrm{~Hz}, 1 \mathrm{H}, \mathrm{CHO}), 7.65(\mathrm{~d}, J=16.0 \mathrm{~Hz}, 1 \mathrm{H}$, $\mathrm{CH}=\mathrm{CH}-\mathrm{COO}$ ), 7.49 (d, $J=8.8 \mathrm{~Hz}, 1 \mathrm{H}, \mathrm{ArH}), 6.90$ (d, $J=8.8 \mathrm{~Hz}, 1 \mathrm{H}, \mathrm{ArH}), 6.40$ (d, $J=16.0$ $\mathrm{Hz}, 1 \mathrm{H}, \mathrm{CH}=\mathrm{CH}-\mathrm{COO}$ ), 5.58 (br s, 1H, CH-O-C=O), 5.36 (t, J=6.8 Hz, 1H, (Me)C=CH), 3.85 (s, 3H, OMe), 3.35 (s, 3H, OMe), 3.24 (dd, $J=10.8,2.8 \mathrm{~Hz}, 1 \mathrm{H}, \mathrm{CH}-\mathrm{OMe}$ ), 2.79 (t, $J=10.8$ $\mathrm{Hz}, 1 \mathrm{H}, \mathrm{CH}-\mathrm{C}(\mathrm{Me})=\mathrm{CH}), 2.38(\mathrm{td}, J=10.8,3.7 \mathrm{~Hz}, 1 \mathrm{H}, \mathrm{CH}-\mathrm{CHO}), 2.15(\mathrm{dq}, J=15.1,3.7 \mathrm{~Hz}$, $1 \mathrm{H}, \mathrm{CH}-\mathrm{CH}(\mathrm{CHO})), 2.02\left(\mathrm{~m}, 2 \mathrm{H}, \mathrm{C}=\mathrm{CH}-\mathrm{CH}_{2}\right), 1.75(\mathrm{~m}, 1 \mathrm{H}, \mathrm{CHH}-\mathrm{CH}(\mathrm{CHO}), 1.62$ (s, 3H, $\mathrm{Me}-\mathrm{C}=\mathrm{CH}), 1.61-1.47\left(\mathrm{~m}, 3 \mathrm{H}, \mathrm{CH}(\mathrm{Me})_{2} \& \mathrm{CH}_{2} \mathrm{CH}(\mathrm{O}-\mathrm{C}=\mathrm{O})\right), 1.20$ (q, J = 7.0 Hz, 2H, $\mathrm{CH}_{2}$ $\left.\mathrm{CH}(\mathrm{Me})_{2}\right), 0.87 \& 0.85\left(2 \mathrm{~d}, J=6.5 \mathrm{~Hz}, 6 \mathrm{H}, \mathrm{CH}(\mathrm{Me})_{2}\right)$.

${ }^{13} \mathrm{C}$ NMR $\left(100 \mathrm{MHz}, \mathrm{CDCl}_{3}\right): 203.2,166.8,161.4,144.7,131.8,130.0,129.8,127.2,115.8$, 114.3, 80.1, 66.4, 57.3, 55.4, 51.1, 47.9, 38.6, 27.6, 27.5, 25.7, 22.5, 22.4, 20.1, 12.9.

HRMS (FAB) $\mathrm{m} / \mathrm{z}$ found 430.2727 , calcd for $\mathrm{C}_{26} \mathrm{H}_{36} \mathrm{O}_{5} \mathrm{~m} / \mathrm{z}: 430.2719$. 
